University of Rhode Island

DigitalCommons@URI

Open Access Master's Theses

1979

\title{
FUELWOOD PRODUCTION OF MIXED HARDWOODS ON MESIC SITES IN SOUTHERN RHODE ISLAND
}

Jeffrey Alan Bridge

University of Rhode Island

Follow this and additional works at: https://digitalcommons.uri.edu/theses

\section{Recommended Citation}

Bridge, Jeffrey Alan, "FUELWOOD PRODUCTION OF MIXED HARDWOODS ON MESIC SITES IN SOUTHERN RHODE ISLAND" (1979). Open Access Master's Theses. Paper 177.

https://digitalcommons.uri.edu/theses/177

This Thesis is brought to you for free and open access by DigitalCommons@URI. It has been accepted for inclusion in Open Access Master's Theses by an authorized administrator of DigitalCommons@URI. For more information, please contact digitalcommons-group@uri.edu. 


\section{FUELWOOD PRODUCTION OF MIXED \\ HARDWOODS ON MESIC SITES IN \\ SOUTHERN RHODE ISLAND \\ BY \\ JEFFREY ALAN BRIDGE}

A THESIS SUBMITTED IN PARTIAL FULFILLMENT OF THE REQUIREMENTS FOR THE DEGREE OF MASTER OF SCIENCE

IN

PLANT AND SOIL SCIENCE

UNIVERSITY OF RHODE ISLAND 


\section{MASTER OF SCIENCE THESIS}

OF

JEFFREY ALAN BRIDGE

Approved:

Thesis Committee

Major Professor

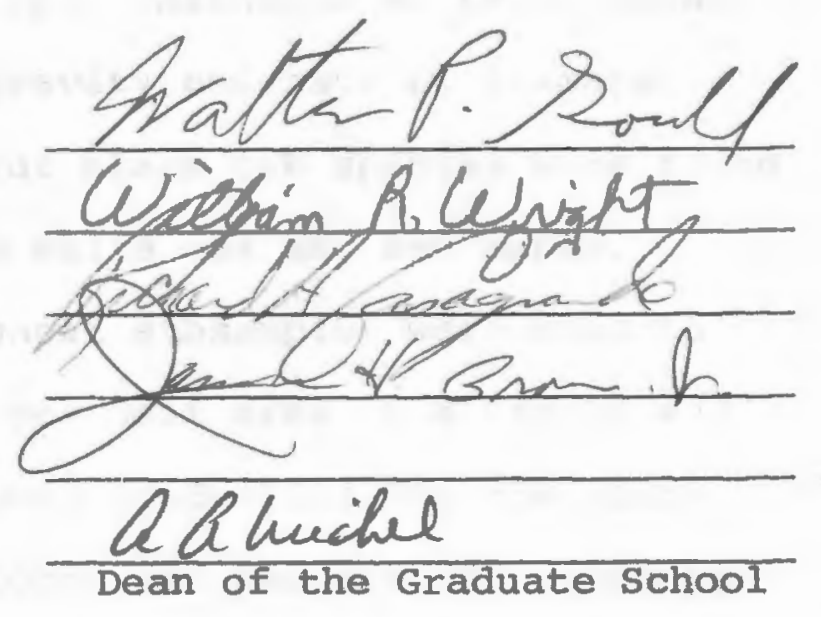

UNIVERSITY OF RHODE ISLAND

1979 


\section{ABSTRACT}

Fuelwood biomass production was determined for three coppice origin, even-aged, mixed-hardwood stands growing on moderately well-drained sites in Washington County, Rhode Island. A total of 93 trees including mixed-oaks and red maple, ranging from 7.6 to $30.5 \mathrm{~cm}$ in diameter were destructively sampled.

Sample trees were felled, sectioned and separated into two components: stemwood and branchwood. Total green weight by component was recorded for each tree in the field. Components were subsampled to permit oven-dry weight and specific gravity determinations. Although no relationship was found between specific gravity and rate of diameter growth, specific gravities for black oak species were found significantly different from white oak and red maple.

Values based upon component subsamples were used to project fuelwood production per unit area on a weight and volume basis. Average cordwood production for the study sites was approximately 73 cords per hectare $(30$ cords per acre), while mean annual increment was 1.6 cords per hectare (.65 cords per acre). Fuelwood estimates closely paralleled those of previous studies conducted for Appalachian hardwoods in southern New England.

Increased fuelwood utilization has created a demand for methods to quickly estimate tree and stand biomass. This paper presents equations and tables to estimate green and 
oven-dry weights for individual trees and species, diameter classes and entire stands. Weight estimates were obtained through use of equations developed by regression analysis. Analyses indicated natural logarithm transformation on diameter and tree basal area multiplied by total tree height accounted for most of the variation in whole-tree weight. Estimates of total stand biomass were developed from equations including natural log transformation on basal area per unit area, and total stand basal area multiplied by the height of the tree of mean basal area. Coefficients of determination, $\mathrm{R}^{2}$, calculated for stand biomass estimates were .88 using basal area and .91 using basal area times height.

An attempt was made to relate differences in site productivity to soil characteristics. It was established that soil texture, organic carbon content, available water and depth of solum are strongly correlated with tree-growth parameters. However, sample size was insufficient to permit the development of meaningful equations for determining site productivity. Also, results indicated that biotic competition may overshadow the importance of edaphic factors in influencing tree growth.

Tree height did not appear to work well in indexing site productivity. Site index was variable on soils considered similar in terms of their abilities to grow trees. 
ACKNOWLEDGEMENTS

The author wishes to express his sincere gratitude to Drs. Walter P. Gould and James H. Brown, Jr., Associate Professors of Forest and Wildlife Management, for their valuable assistance and inspiration during the course of this investigation. Gratitude is also extended to Dr. William R. Wright, Associate Professor of Plant and Soil science, for his guidance in all soil aspects of this study. I also wish to thank Dr. James F. Heltshe, Assistant Professor of Statistics, for his suggestions and assistance with computer techniques and statistical interpretation.

In addition, appreciation is expressed to my fellow graduate students, Benjamin V. Harrison and Peter G. Stevenson, for their advice and amiability during the past two years. I would also like to acknowledge Peter s. Schauer for his assistance in regard to soil analysis procedures. A very special thanks is extended to my wife, Elaine, for her constant encouragement and understanding during the preparation of this thesis.

This research was sponsored and supported by funds from the United States Department of Agriculture under the Cooperative Forestry Research McIntire-Stennis Act. 
TABLE OF CONTENTS

CHAPTER

$\underline{\text { PAGE }}$

I. INTRODUCTION . . . . . . . . . . . . 1

II. LITERATURE REVIEW. . . . . . . . . . 4

A. Sampling Procedures. . . . . . . . 4

B. Statistical Analysis . . . . . . 6

III. STUDY AREAS. . . . . . . . . . 10

A. Location . . . . . . . . . 10

B. Vegetation........... 13

C. Soils and Topography ......... 15

D. Climate............ 17

IV. STUDY METHODS AND PROCEDURES .......... 19

A. Plot Establishment and Tree Measurements . . 19

B. Biomass Determinations ........ 19

C. Soil Analysis. . . . . . . . . . 22

D. Statistical Analysis . . . . . . . 25

V. RESULTS AND DISCUSSION . . . . . . . . . 26

A. Stand and Site Characteristics..... 26

1. Tree Characteristics ....... . 26

2. Species Composition. . . . . . . . 31

3. Tree Radial Growth ........ . . 31

4. Site Index . . . . . . . . 35

B. Site Productivity. . . . . . . 36

1. Fuelwood Production. . . . . . . 36

2. Regression Analyses and Yield Tables.. 40 
a. Estimating Weights of Individual Trees............ 42

b. Estimating stand Weights . . . . 46

3. Site Comparisons . . . . . . 50

a. Yield Comparisons. . . . . . 50

b. Soil-Productivity Relationships. . 54

VI. SUMMARY AND CONCLUSIONS. . . . . . . . . 60

REFERENCES CITED . . . . . . . . . . 66

APPENDIX

A. Soil Profile Descriptions. . . . . . 75

B. Laboratory Soil Analysis by Study Area . 91

c. Nutrient Analysis for Scio silt Loam . . 95

D. Sample Tree Data by Study Area . . . . 97 


\section{LIST OF TABLES}

1. Soil Classification, Solum Depth and Slope for the Study Areas. . . . . . . . . . . . . 16

2. Stand Characteristics. . . . . . . . . 27

3. Average Moisture Content and Specific Gravity for Species by Study Area. . . . . . . . . . 28

4. Species Composition of Stands on the Study Areas. . . . . . . . . . . . . . 3 32

5. Dry-Weight Yields and Cordwood Production for Stands on the Study Areas. . . . . . . . 37

6. Average Oven-dry Weights of Trees by Diameter Class Separated by species . . . . . . . . 39

7. Cordwood Biomass, Energy Values and Heat Equivalents of Various Woods . . . . . . . . 41

8. Diameter Class Oven-dry Weight Estimates Using Regression Models 8 and 9........... 47

9. Estimates of Oven-dry Weight Biomass ( $\mathrm{kg} / \mathrm{ha})$ by Study Area Using Regression Models 10 and 11

10. Production Yields of Even-aged, Second-growth Hardwoods by Study Area Compared to Schnur's Yield Tables . . . . . . . . . . . . . 52

11. Average Soil Properties for A and B Horizons on the Study Sites........... . . 55 


\section{IIST OF ILLUSTRATIONS}

1. Location of study Areas in South Kingstown,

Rhode Island. From Left to Right: (I) Great

Swamp I; (2) Great Swamp II; (3) Hazard

Tract. . . . . . . . . . . 12

2. Growth Rate Curves for the Study Areas.

From Left to Right: (I) Hazard Tract; (2)

Great Swamp I; (3) Great Swamp II. . . . . . 34 


\section{INTRODUCTION}

The current energy crisis has fostered a renewed interest in the use of wood for fuel. In fact, the use of wood as an energy source has increased dramatically in the last several years. It appears that this trend will continue, particularly in southern New England where forests occur in close proximity to large population centers. Presently, knowledge concerning the potential of this forest to fulfill increasing demands is not known.

The quantity of fuelwood currently harvested in Rhode Island, and the potential demand for fuelwood are also unknown. Several studies in the Northeast have reported substantial use of firewood by homeowners either as a primary or secondary source of heat (Dalton et al., 1977). A recent survey by stoddard (1979) in Washington County, Rhode Island, indicates that fifty percent of homeowners are burning fuelwood with an average household consumption of two cords per season.

Extensive and repeated clear-cuttings, forest fires, severe weather phenomena, and disease and insect infestations have exerted cumulative effects resulting in a predominately even-aged, mixed-oak forest of sprout origin. Little appears to be known of the present productivity of the southern New England sprout forest in terms of biomass production. Toumey and Korstian (1947) speculated that repeated sprouting of vegetatively propagated trees may 
result in reduced vigor with each successive cutting. Previous work by Roth and Hepting (1943) illustrated that the ability of oaks to sprout was inversely related to tree age and stump size. However, Wendel (1975) investigated sprouting ability in Appalachian hardwoods and concluded that hardwoods sprouted vigorously regardless of stump size, and produced excellent height and diameter growth on good stem form. Little actual work has been done in relating stump vigor to stem biomass production. Moreover, knowledge concerning the ability of sprout-oak forests in southern New England to produce fuelwood is incomplete. Morrow and Gage (1977) estimated that typical, unmanaged Northeastern forest stands contain between 20 and 40 cords per acre. They further estimated mean annual increment to average onehalf cord per acre, with better sites capable of producing at least one cord per acre per year. Very little work, however, has been done to relate wood production to site conditions in the southern New England area.

McGahan et al., (1961) were unable to develop significant site-growth relationships for mixed-oaks in Rhode Island. Variables including tree parameters, soil drainage, slope, basal area and land use did not adequately account for differences in height growth between study areas. Wright (Pers. comm.) speculates that soil physical and chemical properties may be responsible for differences in site productivity. Meaningful correlations between soil 
characteristics and wood production could serve as a valuable tool in assessing and evaluating the potential of a given site to produce fuelwood. Information from this study, in combination with cordwood production data from other typical sites in the region, could be used to guide management decisions and recommendations for purposes of growing fuelwood to meet potential demand. Therefore, this study will attempt to determine fuelwood biomass production of several hardwood stands growing under various site conditions on moderately well-drained soils in Southern Rhode Island. In addition, relationships between soil characteristics and site productivity will be evaluated. 


\section{IITERATURE REVIEW}

Biomass is becoming an important measure for forest managers and forest ecologists. As forest management moves toward complete-tree utilization, biomass may replace volume as a measure of yield and further be used as a measure of site productivity (Young, 1973). Following the International Biological Program, biomass and productivity studies have increased greatly in number.

Wood weight measurement studies have been in progress in Canada for some time. The Wood Measurement Committee of the Canadian Pulp and Paper Association (1928) conducted early investigations and recognized the utility of weight measurements for operational purposes. Today, biomass data for a variety of Canadian forest types provides a background of information that is rapidly accumulating. During the last two decades, forest weight studies have been undertaken in relation to harvesting (Keen, 1963), productivity (Ovington, 1962; Baskerville, 1965; Wells, Jorgensen and Burnette, 1975; Johnston and Bartos, 1977) and complete-tree utilization (Young, 1964; Keays, 1971). The acquisition of such data is laborious and involves a considerable expenditure of time and funds; therefore, it is essential that biomass studies are well planned with regard to collection and statistical analysis of data.

A. Sampling Procedures

Reliable sampling methods are essential for interpreta- 
tion and comparison of results. Ovington, Forrest and Armstrong (1967), Madgwick (1971), Crow (1971) and Wells et al. (1975) state that stratified sampling by diameter class provides better estimates of biomass than complete random sampling. Stratified random sampling by diameter class is often used for sampling uneven-aged stands whereas complete random sampling is commonly used in even-aged stands (Baskerville, 1965; Whittaker and Woodwell, 1969).

Complete random sampling involves the "mean tree" technique which estimates biomass for an entire stand by harvesting and weighing one or more trees of mean dimension. Sample tree data are converted to a landarea basis by multiplying the biomass of sample tree(s) by the average number of trees per unit area (Art and Marks, 1971). This technique has been used extensively in plantations and uniform even-aged stands to provide an expedient estimate of biomass production. However, it is not without error. The shortcoming of this method is the difficulty in selecting a tree of mean dimension that approximates a tree of mean biomass (Crow, 1971). Moreover, in comparison to stratified sampling, the mean tree technique provides estimates having less precision and greater bias (Madgwick, 1971). 
B. Statistical Analysis

Detailed studies have developed regression models for estimating biomass for species, locale and regional areas (Green and Grigal, 1978). Biomass estimation equations should involve independent variables that are commonly determined in forest mensurational and ecological research that explain most of the variation in weight of trees measured.

Tree stem diameter at 4.5 feet above the ground or breast height (dbh) has been shown to account for most of the variation in weight according to Baskerville (1965), Weetman and Harland (1964), Crow (1971), Skeen (1973), Johnston and Bartos (1977), Wartluft (1977) and Wiant and Castaneda (1978). Others have successfully incorporated height with dbh in developing accurate biomass estimation equations (Young, Strand, and Altenberger, 1964; Haush, Miller and Beers, 1972; Clark and Taras, 1976; Green and Grigal, 1978). However, Crow (1971) and wiant and Castaneda (1978) state that with uniform, vertical extension of stands, incorporation of total tree height as an independent variable does not improve reliability of regression estimates. Johnstone (1971) further suggests that any attempt to assess site productivity in terms of conventional height-age relationships may result in erroneous conclusions when considering mean height data of similar stands. However, 
Schlaegel (1975) did develop a significant regression equation using height in combination with basal area to accurately estimate biomass for trees, diameter classes and forest stands.

Wells et al. (1975) used tree basal areas as the only independent variable and successfully estimated biomass of a loblolly pine plantation. Basal area is often used because it may be directly converted from tree to stand estimates in point sampling (Smith, 1967) and is easily measured in the field. However, use of tree or stand basal area to estimate weight, while very effective for average trees, may mask exceptions completely.

Difficulty in using regression equations to estimate biomass is caused by the fact that size and weights of tree and stand components are determined by a variety of variables (Smith, 1971). Using weight reduces the need to determine the many elements of size, shape and substance that are incorporated into tree and stand growth. Although use of weight has advantages, it often oversimplifies and obscures the importance of these elements (Smith, 1971). In order to understand tree growth well enough to manipulate growth processes to desired objectives, it is necessary to study trees on an individual rather than on a stand basis (Smith, Kerr and Csizmazia, 1961). 
Both Iinear and allometric regression models have been used in biomass studies. Linear regression models involving untransformed data have been used for simplicity and ease of interpretation (Schreuder and Swank, 1971), and to avoid serious bias inherent in parameter estimates involving allometric functions (Crow, 1971). However, Young et al. (1964) believe linear relationships have heterogeneous variance and lower precision for biomass data. Most investigators use allometric equations so as to achieve a higher squared correlation coefficient, $R^{2}$, and to reduce heteroscedasticity in order to meet the basic assumptions of regression analysis.

Natural logarithm transformation on dependent and independent values has proven superior in estimating biomass regardless of selected variables. Furnival (1961) and Cox (1961) favor the use of natural log transformations in that they simplify calculations and do not affect conclusions. Iimitations on the precision of estimates derived from allometric relationships are a function of the accuracy and representativeness of the data from which the equations are founded (Johnstone, 1971). The number of observations used to establish a regression equation must be sufficient to ensure a true representation of the relationship. Also, little advantage seems to be gained by using multiple regression in place of 
simple regression functions (Crow, 1971).

Regression equations should not be extrapolated beyond the range of data on which they are based. However, they may provide at least tentative guidelines to develop estimates for many circumstances not involved in the basic data (Smith, 1971). Schreuder and Swank (1971) caution that the usual measure of goodness of fit, $R^{2}$, may produce misleading results. This measure is valid if conditions under which it is meant to apply are met. Random sampling from a multivariate, normal population is a primary requirement. This assumption, however, is often violated, since selection of sample trees may not be totally random as, for example, when the stratified random sampling technique is used. Very often, the population is not even approximately normal. For instance, the distribution of tree diameters (D) may be approximately normal, however, the variable $\log _{e} D$, that is most often used, is not normally distributed; therefore, the assumption is violated and the concept of $R^{2}$ can be meaningless. Although the $\mathrm{R}^{2}$ concept is not always meaningful; it is easily calculated, comparable, extremely accurate and commonly used in biomass studies (Schreuder and Swank, 1971). 
III. STUDY AREAS

This study was conducted during the summer and fall of 1978 in three mixed-hardwood stands located in South Kingstown, Rhode Island. Stands selected for study were fully-stocked and similar in elevation, topography and species composition. All areas supported stands of evenaged mixed-hardwoods of coppice origin. Moderately welldrained sites served as the basis for selection of study areas. Each study area was located on a different soil series so as to obtain some indication of variation in wood production associated with soil characteristics on moderately well-drained soils. Two sample plots were randomly established in each study area.

A. Location

Location of each study area is illustrated in Figure 1. Study area 1, designated as Great Swamp I, is located within the Great Swamp Wildlife Management Area in South Kingstown, Rhode Island, at $71^{\circ}-35^{\prime}-11^{\prime \prime} \mathrm{W}$ longitude and $41^{\circ}-27^{\prime}-51^{\prime \prime} \mathrm{N}$ latitude.

Study area 2, designated as Great Swamp IIr is also situated within the Great Swamp Wildlife Management Area at $71^{\circ}-34^{\prime}-31^{\prime \prime} \mathrm{W}$ longitude and $41^{\circ}-27^{\prime}-57^{\prime \prime} \mathrm{N}$ latitude.

Study area 3 is located on the University of Rhode Island Hazard Tract in South Kingstown, Rhode Island, at $71^{\circ}-29^{\prime}-26^{\prime \prime}$ W longitude and $41^{\circ}-27^{\prime}-37^{\prime \prime} \mathrm{N}$ latitude. 
Figure 1. Location of Study Areas in South Kingstown, Rhode Island. From Left to Right: (1) Great Swamp I; (2) Great Swamp II; (3) Hazard Tract. 


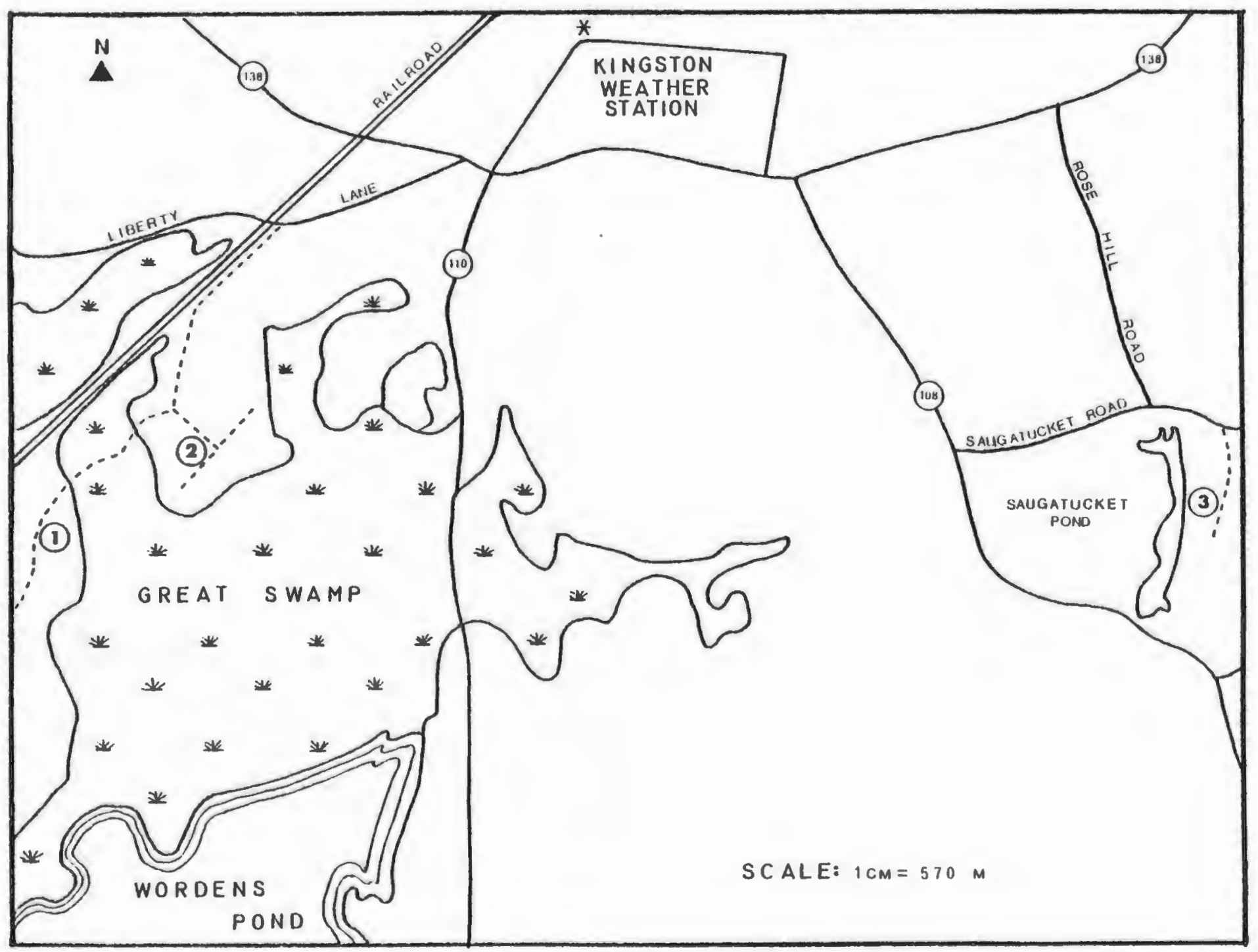


B. Vegetation

Three mixed-hardwood stands representing forest types most commonly occurring in Rhode Island were studied. A mixture of oaks, primarily of coppice origin, occurred in the overstory on all study sites. In addition, red maple (Acer rubrum L.) was an important component of the overstory on two of the three study areas. Evenaged, mixed-oak stands of coppice origin dominate most of Rhode Island's 404,000 acres of forest land. According to Brown (1960), two major factors responsible for these stands have been the widespread occurrence of wild fires and repeated clear-cuttings.

\section{Great Swamp I}

The overstory (tree stems greater than $4.1 \mathrm{~cm}$ dbh) on this area is dominated by black oak (quercus velutina Lam.) and white oak (Q. alba L.). Nomenclature is according to Fernald (1950). Associated species of lesser importance include red oak ( $Q$. rubra L.), swamp white oak (Q. bicolor willd.), black gum (Nyssa sylvatica Marsh.) and American holly (Ilex opaca Ait.).

Understory vegetation (woody stems less than $4.1 \mathrm{~cm}$ dbh) is sparse, consisting of black huckleberry (Gaylussacia baccata Wang.) and low-bush blueberry (Vaccinium vaccillans Torr.). Tree seedlings and 
saplings are sparse on this study area. Also, the area supports a thick sedge (Carex sp.) ground cover.

\section{Great Swamp II}

The predominate overstory species in this stand is red maple. Other species present are white, black and swamp white oak, black gum, sassafras (Sassafras albidum Nutt.) and pitch pine (Pinus rigida Mill.).

The understory consists of a tall, dense, ericaceous shrub layer of mountain laurel (Kalmia latifolia L.), great laurel (Rhododendron maximum L.) and high-bush blueberry (Vaccinium corymbosum L.). Tree seedlings and saplings, as well as ground cover, are absent.

\section{Hazard Tract}

Major species occurring in the overstory are black, white and scarlet oak (Quercus coccinea Muench.) and red maple. Minor species present, generally in small numbers, are red oak, gray birch (Betula populifolia Marsh.) and planted white spruce (Picea glauca Moench.).

The understory vegetation on this site consists primarily of a mixture of black huckleberry and lowbush blueberry of moderate density. Other species present are greenbrier (Smilax rotundifolia L.) and sheep laurel (Kalmia angustifolia L.). Red maple, 
white pine (Pinus strobus L.) and Eastern hemlock (Tsuga canadensis Carr.), seedlings and saplings are present throughout the area.

C. Soils and Topography

Soils on all six study plots are moderately well-drained having originated from either glacial granitic till or outwash. However, soils differ between and within study areas in terms of classification and associated characteristics as demonstrated in Table 1.

1. Great Swamp I

Soil in this area is a relatively shallow, Birchwood loamy sand. ${ }^{1}$ A fragipan containing large amounts of coarse gravel occurs at a depth of approximately $90 \mathrm{~cm}$. The site, located at 36 meters above mean sea level, exhibits a gently rolling, stony topography.

2. Great Swamp II

This study area is located on two soil types; one study plot is situated on a Woodbridge sandy loam and the other on a sutton sandy loam. Subsurface horizons in each soil type contain large amounts of coarse fragments, however, depth of fragipans in each soil type differ. A fragipan appears at approximately $90 \mathrm{~cm}$ in the Woodbridge, whereas

${ }^{I}$ Soil series were determined by Dr. William R. Wright, Soil Scientist, University of Rhode Island. 
TABLE 1. Soil Classification, Solum Depth and slope for the Study Areas.

Study Area Subgroup Family $\quad$ Series $\quad$\begin{tabular}{c} 
Textural Class Depth (cm) Slope (\%) \\
\hline
\end{tabular}

Great Swamp I

\begin{tabular}{|c|c|c|c|c|c|c|c|}
\hline Plot 1 & $\begin{array}{c}\text { Typic } \\
\text { Fragiochrept }\end{array}$ & $\begin{array}{l}\text { Sandy, } \\
\text { mixed mesic }\end{array}$ & Birchwood & loamy & sand & 90 & $0-3$ \\
\hline P1ot 2 & $\begin{array}{c}\text { Typic } \\
\text { Fragiochrept }\end{array}$ & $\begin{array}{l}\text { Sandy, } \\
\text { mixed mesic }\end{array}$ & Birchwood & loamy & sand & 72.5 & $3-8$ \\
\hline
\end{tabular}

Great Swamp II

$\begin{array}{cccccc}\text { Plot } 1 & \begin{array}{c}\text { Typic } \\ \text { Fragiochrept }\end{array} & \begin{array}{c}\text { Coarse-loamy, } \\ \text { mixed mesic }\end{array} & \text { woodbridge sandy loam } & 70 & 0-3 \\ \text { Plot } 2 & \begin{array}{c}\text { Umbric } \\ \text { Dystrochrept }\end{array} & \begin{array}{c}\text { Coarse-loamy, } \\ \text { mixed mesic }\end{array} & \text { Sutton sandy loam } & 65 & 0-3\end{array}$

\section{Hazard Tract}

$\begin{array}{cccccc}\text { Plot } 1 & \begin{array}{c}\text { Umbric } \\ \text { Dystrochrept }\end{array} & \begin{array}{c}\text { Coarse-silty, } \\ \text { mixed mesic }\end{array} & \text { Scio } & \text { silt loam } & 80 \\ \text { Plot } 2 & \begin{array}{c}\text { Umbric } \\ \text { Dystrochrept }\end{array} & \begin{array}{c}\text { Coarse-1oamy, } \\ \text { mixed mesic }\end{array} & \text { Scio } & \text { silt loam } & 82.5\end{array}$


Sutton displays a fragipan below the control section at $137 \mathrm{~cm}$.

3. Hazard Tract

This area, located 12 meters above mean sea level on gently rolling, very stony terrain, occurs on a Scio silt loam. Soil is deep without a fragipan, and originated from outwash, in contrast to the Great Swamp study areas where soils originated from glacial till. Subsurface horizons contain coarse fragments. Complete profile descriptions of study areas are given in Appendix A.

The presence of plow horizons in each soil profile indicates past agricultural use. There was no evidence of past fires occurring in recent years on any of the study areas.

\section{Climate}

The National Oceanic and Atmospheric Administration (NOAA) station in Kingston, Rhode Island was used as a source of weather data due to its close proximity to the study areas. Average mean temperature for Kingston, Rhode Island for the period $1941-1970$ was $9.4^{\circ} \mathrm{C}$ $\left(48.9^{\circ} \mathrm{F}\right)$ (NOAA, 1974). Due to the effect of the southern New England maritime macroclimate, variation between yearly mean temperatures and monthly mean temperatures is not excessive. 
Mean annual precipitation based on the period 1941-1970 was $112.4 \mathrm{~cm}$ (44.3 inches) (NOAA, 1974). Harris and Odland (1948) stated that precipitation in Rhode Island is uniformly distributed throughout the year with ample quantities normally deposited during the growing season. Due to its coastal location and influence of Narragansett Bay, two commonly destructive climatic forces, hurricanes and ice storms, periodically and extensively damage Rhode Island's forests. 
IV. STUDY METHODS AND PROCEDURES

A. Plot Establishment and Tree Measurements

Two .04 hectare circular plots were randomly established on each of the three study areas. All trees greater than $4.1 \mathrm{~cm}$ ( $1.6 \mathrm{in}) \mathrm{dbh}$ were permanently tagged with enumerated metal strips. Characteristics recorded for each tree included: species, dbh, height, age and crown class. Tree crown classification is according to Smith (1962). Based upon tree data, basal area stocking and site index were determined for each plot. Also, for each plot, indices of species composition including relative density and relative basal area were computed for each species for stems greater than $7.6 \mathrm{~cm}$ (3 in).

\section{B. Biomass Determinations}

Trees within plots were stratified into $2.5 \mathrm{~cm}$ diameter classes, and classes provided a basis for selection of trees for destructive sampling. To ensure representative sampling, the number of trees sampled from each diameter class was selected in proportion to the frequency of individuals within each class. A total of fifteen trees in each plot was randomly selected for destructive sampling to accurately estimate aboveground biomass. For estimating above-ground biomass, Wells et al. (1975) found that a sample of 15 trees per plot provided representative results. 
Sampling was limited to trees greater than $7.6 \mathrm{~cm}$ ( $3 \mathrm{in}$ ) and less than $30.5 \mathrm{~cm}$ (12 in) dbh, however, most sample trees were smaller than $25.4 \mathrm{~cm}$ (10 in). Trees less than $7.6 \mathrm{~cm}$ were considered too small for practical harvest for fuelwood, while trees larger than $30.5 \mathrm{~cm}$, unless of inferior species or of poor form or vigor, would best be left as sawtimber. Only three trees, greater than $30.5 \mathrm{~cm}$ dbh occurred on the plots; two in Hazard Tract and one in Great Swamp II. Thus, biomass estimates very nearly reflect total production for each study area.

The following parameters were recorded for all felled trees: total height, height to live crown and age at stump height. Once felled, sample trees were separated into three components; stemwood (portions of trees having diameters outside bark (dob) greater than $5.1 \mathrm{~cm}$ (2 in)), branchwood (portions of trees having a dob between 5.1 and $2.5 \mathrm{~cm}$ ), and deadwood greater than $2.5 \mathrm{~cm}$ dob. Branchwood less than $2.5 \mathrm{~cm}$ was considered impractical as a source of fuelwood and was not included in biomass determinations.

Total green weight by component for felled trees was recorded at the study sites on a $250 \mathrm{~kg}$ capacity scale. Components were subsampled for specific gravity and percent moisture content; twelve trees on each study area 
for specific gravity determinations and all trees for percent moisture content. In the subsampling process, several disks, $2.5 \mathrm{~cm}$ thick, were removed from each component and weighed immediately following cutting to avoid errors due to moisture loss. Each sample was subsequently labeled and numbered for later identification.

In the laboratory, samples were immersed in water to obtain green disk volume through water displacement. Following volume determinations, samples were oven-dried at $105^{\circ} \mathrm{C}$ for 48 hours to obtain percent moisture content. Oven-dry weight to within one-hundredth of a gram was recorded for each sample. Specific gravity was then determined for each sample based upon green disk volume and oven-dry weight. Subsequently, an average specific gravity for each sample tree was determined. This was accomplished by computing an average specific gravity for stemwood and for branchwood for each sample tree. These values were applied proportionally to the amount of stemwood and branchwood in a given tree to obtain an average specific gravity for that tree.

Percent moisture content was calculated for each disksample using a ratio of oven-dry weight to green weight. Regardless of species, moisture content between stem and branchwood samples was found to be significantly differ- 
ent. Consequently, average moisture content values were calculated separately for stemwood and branchwood. These values were used to project oven-dry weight for stemwood and branchwood of sample trees. Oven-dry weight values weighted proportionally according to total green weight of stemwood and branchwood in a given tree, were used to estimate oven-dry weight of sample trees.

For each plot, sample trees were grouped by diameter class and average oven-dry weight was calculated for each class. Mean oven-dry weight multiplied by the number of trees in a given class provided an estimated total weight per unit area for that diameter class. Subsequently, an estimated weight yield of merchantable fuelwood per plot, inclusive of all diameter classes, was calculated. Sample plot data were combined to arrive at a fuelwood production value for each study area.

Sample sections taken at stump height were used to determine age and mean annual increment of ten codominant and dominant trees from each study area. A Bausch and Lomb stereo-zoom microscope mounted on a DeRouen dendrochronometer was used to measure annual radial growth to $0.01 \mathrm{~mm}$.

C. Soil Analysis

In order to identify conditions that could influence tree growth and site productivity, several soil physical and 
chemical properties were measured in the laboratory. Properties measured were: bulk density, particle size, organic carbon content, percent moisture at field capacity, percent moisture at wilting point, $\mathrm{pH}$, cation exchange capacity, exchangeable acidity and percent base saturation.

Soil profiles were described for each stand from soil pits dug near the center of study plots. ${ }^{1}$ soil samples were obtained from each horizon for textural and chemical analyses. Core samples were taken within plot boundaries to confirm soil profiles as typical for each area.

Bulk density was determined using two techniques. The core sampling method was used where the percentage of sand was high, and for soils with relatively high silt and clay contents, clods were extracted and coated with paraffin to evaluate bulk densities. Soil cores were obtained using a core sampler consisting of a cylindrical sleeve with two $2.5 \mathrm{~cm}$ removable sample cylinders.

Textural class was determined through particle size analysis using the pipette method to separate soil fractions.

${ }^{1}$ Complete profile descriptions are given in Appendix A. 
Organic carbon content was determined through the Walkley-Black method (Black, 1965).

Percent moisture content at field capacity and at permanent wilting point was determined using a pressure membrane apparatus according to the procedure outlined in Methods of Soil Analysis (Black, 1965).

An Orion digital ionalyzer was used to determine hydrogen ion concentration ( $\mathrm{pH})$.

Laboratory analyses for each horizon are contained in Appendix B.

A complete nutrient analysis was conducted for scio silt loam (see Appendix C). Justification for conducting a nutrient analysis on only one soil profile, lay in the fact that each study area had similar land use (past agriculture) and an extremely small range in $\mathrm{pH}$. Since $\mathrm{pH}$ is the principal factor in determining nutrient availability, nutrient status of each profile was assumed to be similar.

Chemical properties measured were: total cation exchange capacity using the ammonium acetate method, exchangeable acidity using the barium chloride -- triethanolamine method, percent base saturation and free iron oxide concentration. In addition, calcium, magnesium, potassium and sodium levels were evaluated through use of a 
spectrophotometer.

Soils were classified according to Soil Taxonomy (USDA, 1975a).

\section{Statistical Analysis}

One way analysis of variance with a standard F-test and Student's " $t$ " test were used to test differences in wood production between study areas. Calculated " $F$ " and " $t$ " values were considered significant at the .05 level and highly significant at the .0l level. Linear, multiple and stepwise regressions were used to evaluate relationships between weight, expressed as the dependent variable, versus a matrix of independent variables including tree, soil and stand characteristics.

Principal component and canonical correlation analyses were conducted to evaluate relationships among variables.

Processing of data was performed on the I.B.M. System 370 computer at the University of Rhode Island Academic Computer Center. 
V. RESULTS AND DISCUSSION

A total of 93 trees from three fully-stocked, evenaged, second-growth hardwood stands was destructively sampled. Characteristics of individual sample trees are contained in Appendix D.

A. Stand and Site Characteristics

1. Tree Characteristics

Stands studied contained trees of similar size and age (see Table 2). The major difference between study areas was the difference in average stand age; average age for trees at the Hazard Tract site was 35 years as opposed to 50 years for Great Swamp I and 52 years for Great Swamp II.

Average tree moisture contents for species and study areas are presented in Table 3 . Species in the black oak group which included black, red and scarlet oaks contained 74 percent moisture on an ovendry weight basis, while red maple and white oak contained 60 and 66 percent, respectively. Sassafras and black gum with 82 and 84 percent contained more moisture than other species, but values are based only on single trees of each species. Differences in tree moisture contents between areas and species were not significant. 
TABLE 3. Average Moisture Content and Specific Gravity for Species by Study Area

\begin{tabular}{llll}
\hline Study Area & Species & Moisture Content & \\
Mean & Range & $\frac{\text { Specific Gravity }}{\text { Mean }}$ \\
\hline
\end{tabular}

$$
-----0 / 0----
$$

Great Swamp I

Black Oak
White Oak

Black Gum

73
65
84
$68-87$
$62-75$
--

Great Swamp II

$\begin{array}{lll}\text { Black Oak } & 75 & 62-84 \\ \text { White Oak } & 67 & 61-72 \\ \text { Red Maple } & 61 & 55-69 \\ \text { Sassafras } & 82 & ---\end{array}$

Hazard Tract

\begin{abstract}
Black Oak
White Oak

Red Maple
\end{abstract}

$\begin{array}{lc}75 & 60-87 \\ 68 & --- \\ 58 & 56-67\end{array}$

$-----g m / c c$

-- -

.59
$.61-.65$ $.56-.62$

.50

.62
.59

.48

$.57-.63$

---

1 values based upon moisture as a percentage of oven-dry weight.

2 Values based upon green volume and oven-dry weight. 
Tree specific gravities varied within and between species, but averages for species for the study areas were sinilar (see Table 3). A student "t" test of mean specific gravities based upon pooled data from all study areas revealed that average specific gravity for black oak of .63 was significantly different from white oak (.61) at the .05 level and from red maple (.55) at the .01 level. Also, white oak was found to differ significantly from red maple at tie .05 level. Values for each sample tree are contained in Appendix D.

Specific gravities for trees in the black oak group fell within the range of values $(.57-.65)$ given by Forbes (1955) as normal for that group. White oak specific gravities also fell within the accepted range $(.59-.68)$. However, specific gravities for rea maple tended to exceed tine range of values (.49-.54) considerea normal for that species. In fact, mean specific gravity for red maple on the Great Swarnp II study area (.59) fell outside the normal range.

It is widely known that genetic variation causes specific gravity to vary witnin a species in a given location. Also, Panshin and Dezeeuw (1970) indicate that within tree variation is generally so great 
that relationships between specific gravity and location of wood within a tree are impossible to establish. They do indicate, however, that branchwood in ring-porous hardwoods, such as oaks, generally exhibits higher specific gravities than stemwood. This was not the case in the present study; specific gravities varied throughout individual trees so that patterns were not detectable.

In the case of ring-porous hardwoods, faster growth generally results in strong, dense wood higher in specific gravity than slower-growing trees of the same species (Panshin and DeZeeuw, 1970). However, in this study, there did not appear to be a relationship between specific gravity and growth rate of ring-porous oaks. A linear regression of specific gravity and mean annual radial increment failed to show a significant relationship. Paul (1930) also found growth rate had little effect on specific gravity in selected ring-porous species such as ash, hickory and oak.

In diffuse-porous hardwoods, such as red maple, there is little relationship betwen specific gravity of wood and rate of growth (Panshin and Dezeeuw, 1970). However, Paul (1930) discovered 
that for diffuse-porous hardwoods growing under adverse conditions, narrow rings contained a greater amount of porous tissue resulting in lower specific gravity. An examination of specific gravities for diffuse-porous red maples on the study sites shoved no relationship with growth rate.

\section{Species Composition}

Oaks clearly dominate stanas on two of the study areas; Great Swamp I and the Hazard Tract (see Table 4). White oak and red maple contribute considerably less to total stand basal areas than trees of tine black oak group on these study areas.

On Great Swamp II, red maple dominates stand composition. It comprises approximately 70 percent of the basal area present based upon the two plots s ampleà.

\section{Tree Radial Growth}

Radial growth rate curves for the study areas based upon doninant and codominant trees show marked differences between areas (see Figure 2). In the 35-year-old stand at the Hazard Tract, mean annual radial increment averages $3.48 \mathrm{~mm}$, and at the time of sampling there was no indication of a leveling off of radial growth. Radial growth rates for Great 
TABLE 4. Species Composition of Stands on the Study Areas

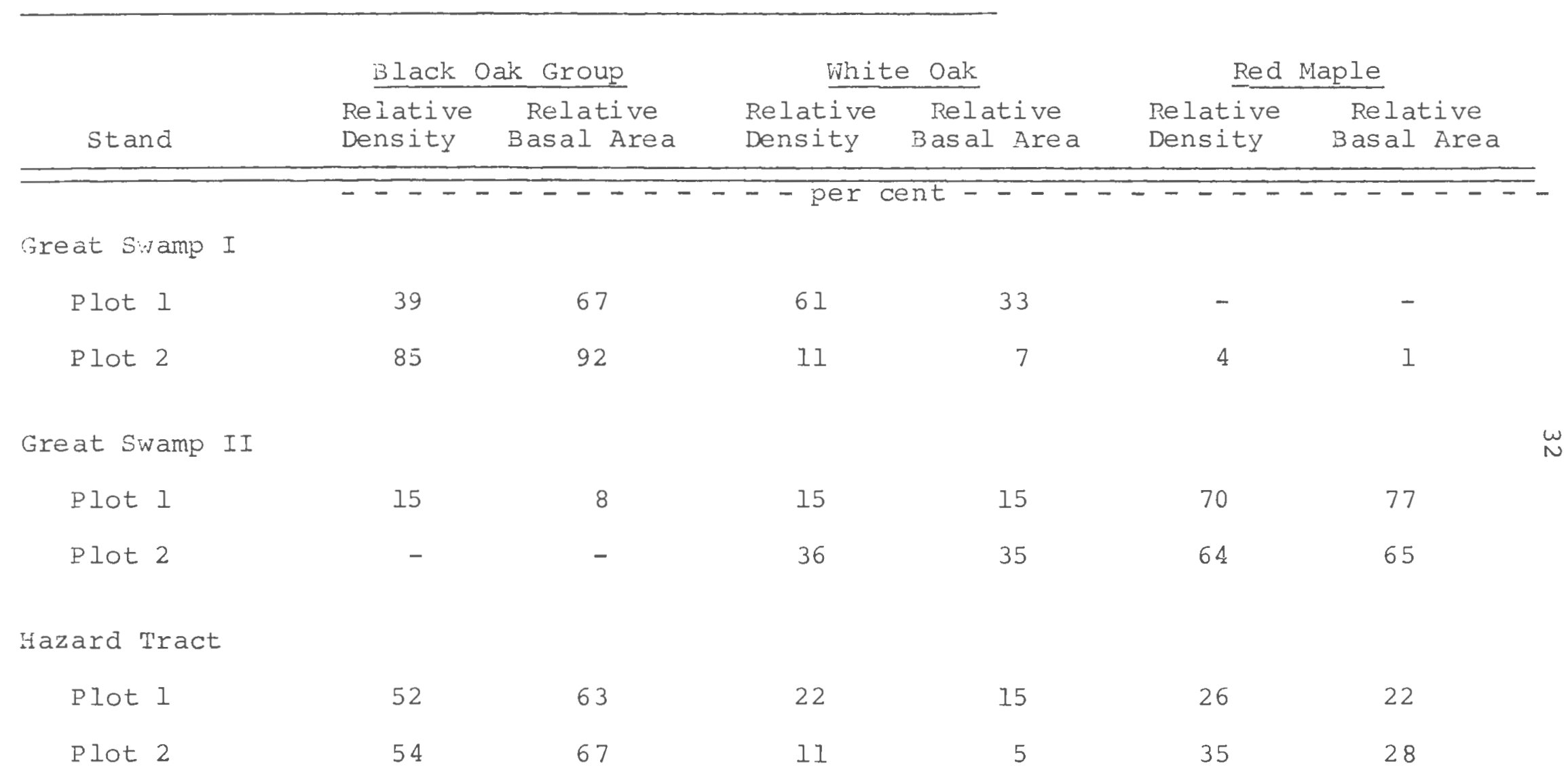


Figure 2. Growth Rate Curves for the Study Areas. Fron Left to Rigit: (1) Hazard Tract; (2) Great Siwamp I; (3) Great Swanp II. 


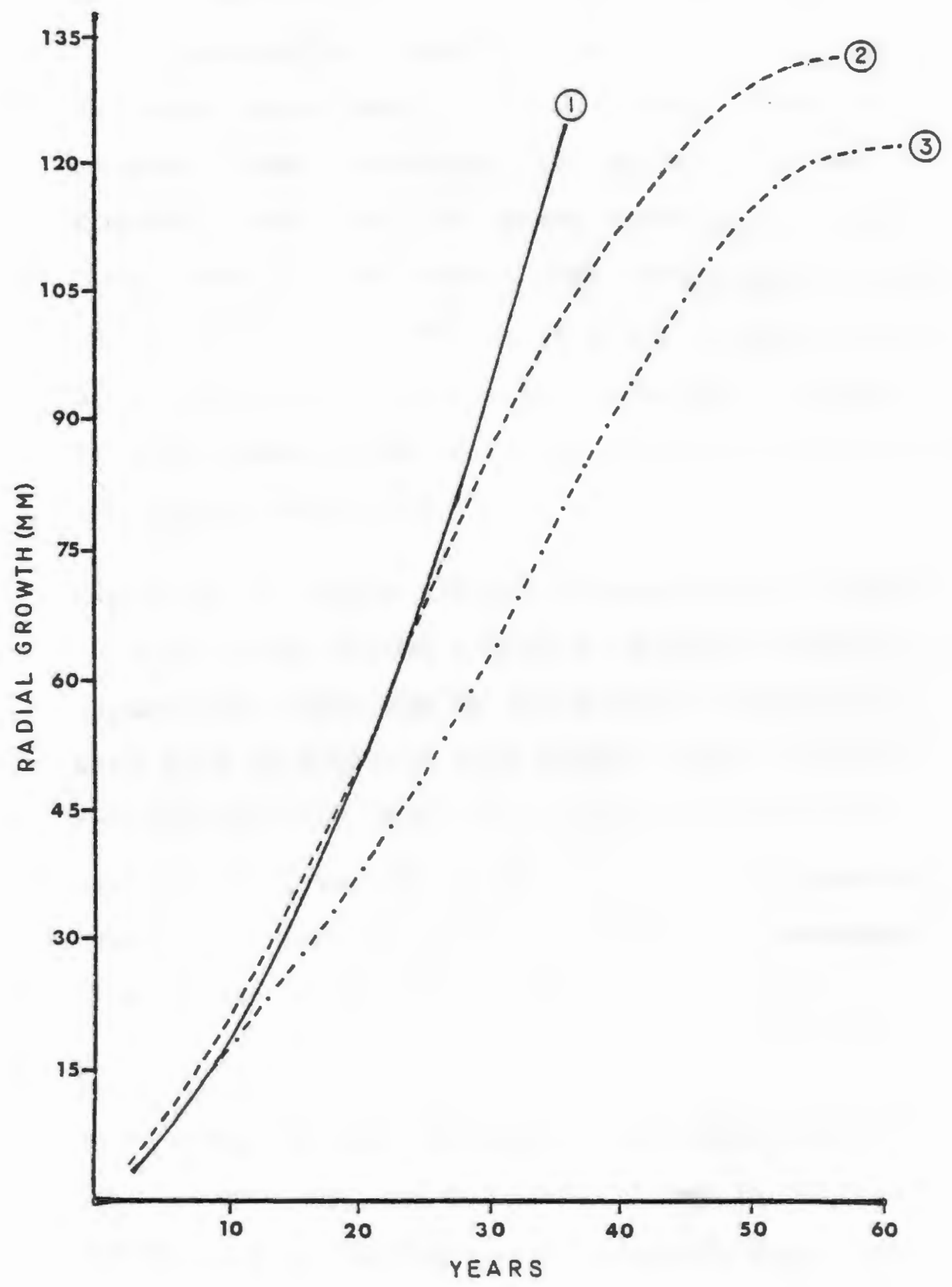


Swamp I paralleled those of the Hazard Tract stand for the first 20 years, but slowed noticeably thereafter followed by a leveling off of growtin at about 50 years. As a result, radial increment for trees on Great Swamp I averaged $2.63 \mathrm{~mm}$ per year, considerably less than the Hazard Tract stand. On Great Swamp II, the growth rate curve began to taper off at 50 years, as did Great Swamp I, but rate of growth was less. Mean radial increment for trees on Great Swamp II was $2.15 \mathrm{~mm}$ per year: lowest of the three study areas.

Accoroing to Schnur (1937), culmination of growth in total cubic volume occurs at avout 50 years for Appalachian hardwoods on all sites. This agrees with data obtainea in this study. Radial growth in the ilazard Tract stand will probably taper off as average stand age approaches 50, but total radial growth and wood production will have far exceeded that in the Great Swamp stands.

\section{Site Iindex}

Site index for oaks (height in feet attained by average dominant an $\vec{a}$ codominant trees in 50 years) was determined for each plot and study area basea upon curves developed by Schnur (1937). The best site index (60) was computed for the Hazard Tract 
stand while site indices for Great Swamp I and Great Swamp II were 45 and 40 , respectively.

B. Site Productivity

1. Fuelwood Production

Dry-weight yields and cordwood production values for individual stands are given in Table 5 .

Except for plot I in the Great Swamp II stand, dryweight and cordwood yields are similar for all plots. However, mean annual cordwood increment differs. Mean annual increment (MAI) of cordwood for the Hazard Tract stand is 2.3 cords per hectare (.94 cords per acre), making it the most productive stand studiea. Cordwood increment for Great Swamp I is only 1.74 cords per hectare (.70 cords per acre) per year which probably reflects the greater average age of the stand. Although average stand age of Great Swamp II is similar to Great Swamp I, annual cordwood increment is only 1.33 cords (.54 cords), reflecting the comparitively low yield from plot 1 in the Great Swamp II stand. Thus, Great Swamp II is the least productive of the three study areas. Despite differences in production rates, data from the three stands were pooled to obtain an estimate of fuelwood production for moderately well-drained 
Table 5. Dry-Weight Yields and Cordwood Production for Stands on the Study Areas

stand

\begin{tabular}{|c|c|c|c|c|}
\hline & & & Mean $\mathrm{Ar}$ & iual \\
\hline & ield & & Incren & $n t$ \\
\hline Dry-weight & & & $\mathrm{Cor}$ & \\
\hline /he & ctare & acre & hectare & acre \\
\hline
\end{tabular}

Great Swamp I

$\begin{array}{llllll}\text { Plot } 1 & 114000 & 84.7 & 34.3 & 1.75 & .71 \\ \text { Plot } 2 & 117825 & 87.7 & 35.5 & 1.73 & .70 \\ \begin{array}{l}\text { Stand } \\ \text { Average }\end{array} & 117150 & 86.2 & 34.9 & 1.74 & .70\end{array}$

Great Swamp II

$\begin{array}{lrrrrr}\text { Plot 1 } & 78725 & 58.5 & 23.7 & 1.11 & .45 \\ \text { Plot } 2 & 108650 & 80.8 & 32.7 & 1.56 & .63 \\ \begin{array}{l}\text { Stand } \\ \text { Average }\end{array} & 93675 & 69.6 & 28.2 & 1.33 & .54\end{array}$

Hazard Tract

$\begin{array}{lrrrrr}\text { Plot 1 } & 121675 & 90.4 & 36.6 & 2.54 & 1.03 \\ \text { Plot 2 } & 98450 & 73.1 & 29.6 & 2.07 & .84 \\ \begin{array}{l}\text { Stand } \\ \text { Average }\end{array} & 110050 & 81.7 & 33.1 & 2.30 & .94\end{array}$

1 plot values projected to unit area values based upon one cord equals $1660 \mathrm{~kg}(3656 \mathrm{lb})$ at 20 percent moisture. 
sites. Pooled data indicate a total yield of 73.1 cords per hectare ( 30 cords per acre) at age 45 , and a mean annual increment of 1.6 cords per hectare (.65 cords per acre).

In addition to stand age and site conditions, species composition, because of specific gravity differences between species, is important in determining the biomass production of a given area (Schnur, 1937). Data from all three stands were pooled to construct Table 6 which presents average oven-dry weights of trees by diameter class for individual species.

Average weights per diameter class were combined for each species in order to test species totals for differences. Based upon Student " $t$ " tests, the total for the black oak group (1107 kg) differed significantly from white oak $(982.3 \mathrm{~kg})$ and red maple $(867.3 \mathrm{~kg})$ at the .05 level. White oak and red maple totals were not significantly different. Also, average oven-dry weights for trees in the black oak group exceeded white oak and red maple weights for all but one diameter class.

Thus, because of greater average weights regardless of diameter class, black oak would seem to be a 
TABLE 6. Average Oven-dry Weights of Trees by Diameter Class Separated by Species

Diameter

Class

Average Oven-dry Weight

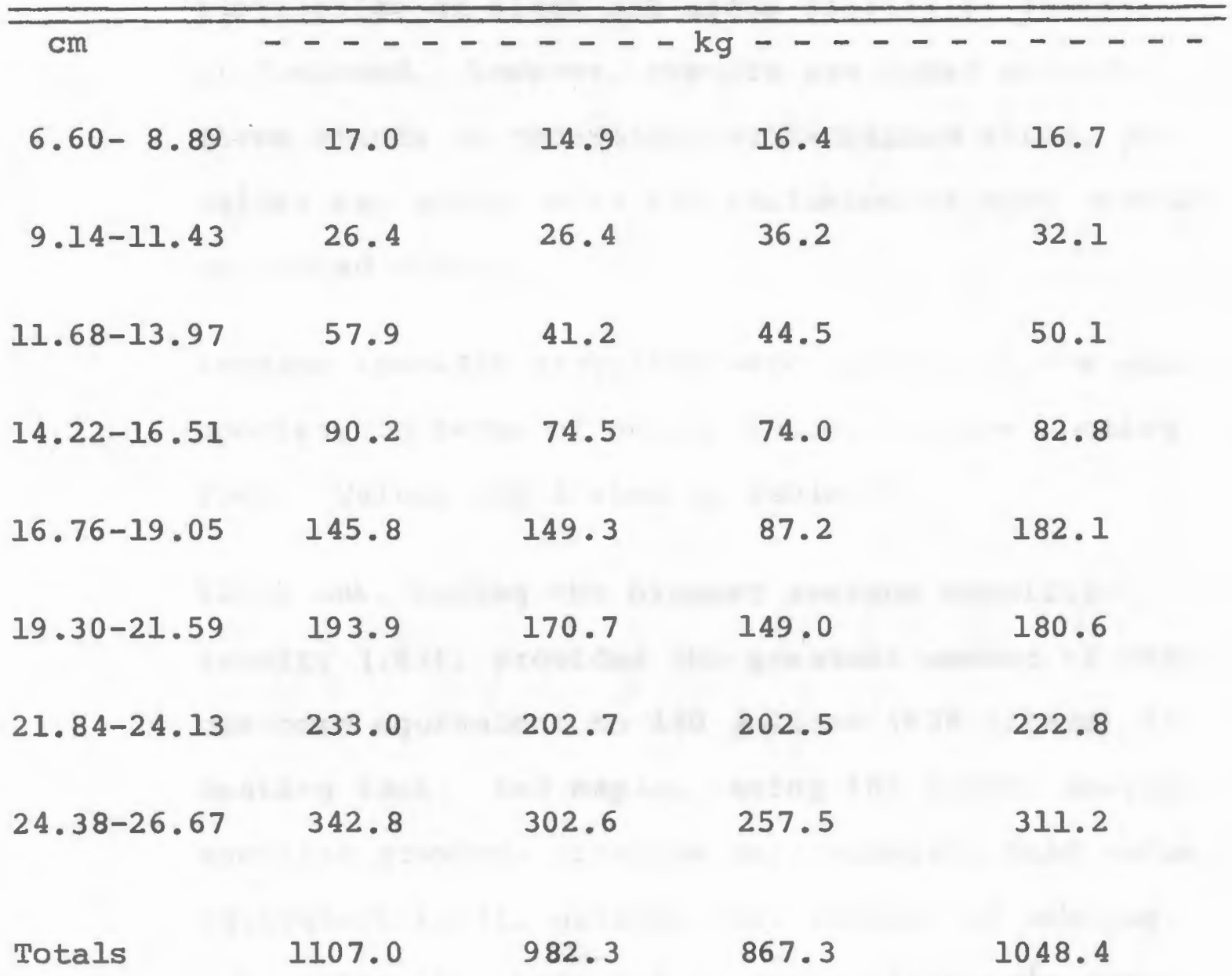


better source of fuelwood than either white oak or red maple. The generally accepted faster growth rates of black oak group species, especially in comparison to white oak, would further support superiority of black oak group species as sources of fuelwood. However, results are based only on three stands on moderately well-drained sites, and values may change with the inclusion of more stands on varied sites.

Average specific gravities were used to relate each species, in terms of energy value, to home heating fuel. Values are listed in Table 7.

Black oak, having the highest average specific gravity (.63), provides the greatest amount of heat: one cord equivalent to 140 gallons (636 liters) of heating fuel. Red maple, having the lowest average specific gravity, provides only moderate heat value equivalent to 115 gallons (523 liters) of heating fuel. For the study areas, taking into consideration species composition, the average heat equivalent of a cord would be equal to 126 gallons (573 liters) of fuel oil.

2. Regression Analyses and Yield Tables An attempt was made to develop regression models 


\begin{tabular}{|c|c|c|c|c|c|c|}
\hline Species & $\begin{array}{c}\text { Weight/cord } \\
(\mathrm{kg})\end{array}$ & $\begin{array}{l}\text { Specific } \\
\text { Gravity } \\
\text { (gm/cc) }\end{array}$ & $\begin{array}{c}\text { Energy } \\
\text { BTU'sl } \\
\text { (Millions) }\end{array}$ & $\begin{array}{c}\text { Efficiency } \\
\text { (percent) }^{2}\end{array}$ & $\begin{array}{l}\text { Unsable } \\
\text { Energy in } \\
\text { BTU's } \\
\text { (millions) }\end{array}$ & $\begin{array}{l}\text { Heating Fuel } \\
\text { Equivalençy } \\
\text { per cord }{ }^{3} \text {. } \\
\text { (gallons) }\end{array}$ \\
\hline
\end{tabular}

\begin{tabular}{|c|c|c|c|c|c|c|c|}
\hline Black Oak & 1725 & .63 & 25 & 55 & 14.0 & 140 & 636 \\
\hline White Oak & 1675 & .61 & 23 & 55 & 12.6 & 126 & 573 \\
\hline Red Maple & 1500 & .55 & 21 & 55 & 11.5 & 115 & 523 \\
\hline Species 4 & & & & & & & \\
\hline Cómbined & 1660 & .60 & 23 & 55 & 12.6 & 126 & 573 \\
\hline
\end{tabular}

1 Based upon values in British thermal units from Morrow and Gage (1977).

2 Based on burning wood at 20 percent moisture in late model wood stove.

3 Based upon 70 percent efficiency for fuel oil.

4 Based upon average weights and specific gravities for all study areas. 
for estimating fuelwood production on moderately well-drained sites. Independent variables included commonly and easily measured tree and site characteristics. The main objective was to develop simple regression models capable of explaining most of the variation in weight (both oven-dry and green) of individual trees and entire stands.

a. Estimating Weights of Individual Trees

Step-wise regression analyses were conducted for each species and study area to determine the importance and significance of independent variables for estimating the weight of individual trees. Independent variables included: tree characteristics - dbh and height; soil characteristics - texture, organic carbon, available water, bulk density, $\mathrm{pH}$ and percent coarse fragments for the surface $91 \mathrm{~cm}$ of soil, depth of solum and depth of the A horizon; and basal area as a measure of stand density.

Analyses indicated dbh accounted for most of the variation in tree weight. Similarly, wiant et al. (1977), Wartluft (1977) and Green and Grigal (1978) also found abh strongly correlated with tree weight and developed regression equations for tree weight as a function of $\mathrm{dbh}$. 
Simple linear regression models combining data from all stuãy areas were developed for each species using $d b h$ to estimate oven-dry weight (ODNT) of individual trees. Furnival (1961), Cox (1961) and Young et al. (1964) suggest using allometric regression equations to increase the coefficient of determination, $\mathrm{R}^{2}$, an $\bar{a}$ reduce heterogeneous variance. Therefore, diameters and oven-dry weights were transformed to natural logs to develop allometric regression equations. Equations and coefficients of determination $\left(R^{2}\right)$ are as follows:

(1) Black Oak $\operatorname{Lin}($ ODiNT $)=$

$$
-.34052+2.65803 \operatorname{Ln}(\mathrm{DBH}) \quad \mathrm{R}^{2}=.96
$$

(2) White Oak $\operatorname{Ln}(O D N T)=$

$$
-.82061+2.84694 \operatorname{Ln}(\mathrm{DBH}) \quad \mathrm{R}^{2}=.93
$$

(3) Red Maple Lin (ODiNT) =

$$
.10594+2.33968 \operatorname{Ln}(\mathrm{DBH}) \quad \mathrm{R}^{2}=.96
$$

Linear regressions for species were tested for differences in slope and level according to Freese (1967). Differences were found to be not significant, and data were combined to produce a single regression applicable to all species. 
In a similar manner, regression models were developed for each study area using dbh to estimate oven-ary weight of individual trees. Regression lines were tested for differences in slope and level: differences were not significant. As a result, data from each study area, including all species, were pooled to develop a single regression to estimate ovenary weight as a function of dbh. In a similar fashion, an allometric equation was developed to predict green weight (GWT) of individual trees. The resulting equations are as follows:

$$
\begin{gathered}
\operatorname{In}(\mathrm{ODWT})=-.39986+2.65919 \operatorname{Ln}(\mathrm{DBH}) \\
\mathrm{R}^{2}=.95 \\
\operatorname{In}(\mathrm{Gr} T)=.11714+2.66262 \mathrm{Ln}(\mathrm{DBH}) \\
\mathrm{R}^{2}=.94
\end{gathered}
$$

Total tree height did not prove significant when included in a multiple regression model with abh. Crow (1971) and Wiant et al. (1977) also found this to be true in their studies and attributed the uniform vertical extension of tree stands, regardless of crown class, as being responsible for the lack of significance. Schlaegel (1975), nowever, developed regression models that successfully incorporated tree 
height (H) with individual tree basal area (B) to estimate green and oven-dry weight for individual trees, diameter classes and entire stands. Estimates of tree oven-dry weight and green weight were made by substituting the combined variable, basal area times height (BH), into the following allometric equations:

$$
\begin{gathered}
\operatorname{Ln}(\mathrm{ODWT})=2.35524+.99342 \mathrm{In}(\mathrm{BH}) \\
\mathrm{R}^{2}=.97 \\
\operatorname{In}(\mathrm{GWT})=2.87187+.99550 \mathrm{In}(\mathrm{BH}) \\
\mathrm{R}^{2}=.97
\end{gathered}
$$

The $\mathrm{R}^{2}$ increases slightly since basal area times total tree height more accurately reflects tree volume than does diameter alone. However, equations using $\mathrm{DBH}$ estimate tree weights with nearly the same precision as the equations using BH. Thus, equations using DBH, because of ease of measurement, appear to provide the best tools for estimating individual tree weights.

A further extension of the individual tree estimate is to estimate weight by diameter class for the purpose of constructing stock tables. Weight estimates can be readily calculated for each diameter class by using 
diameter class basal area for (B) and average total height of trees in that diameter class for (H) in one equation, and mean diameter (D) for trees in a given diameter class in another.

Allometric regression models estimating weight by diameter class are as follows:

(8) $\operatorname{Ln}(O D W T)=-.28603+2.60319 \operatorname{In}(D)$

$$
\mathrm{R}^{2}=.99
$$

(9) $\operatorname{In}(O D W T)=2.39230+.97555 \operatorname{Ln}(\mathrm{BH})$

$$
\mathrm{R}^{2}=.99
$$

Weight estimates derived from each regression model for each diameter class are listed in Table 8. Results indicate that use of mean diameter, (D), slightly underestimates actual values while use of the combined variable, (BH), slightly overestimates actual values. stock tables may be developed for a given stand on moderately well-drained soils using this information in accordance with the number of trees in each diameter class.

b. Estimating Stand Weights

Equations were developed to predict cordwood biomass on a unit area basis. In separate equations, stand basal area (B) and (BH), where $B$ is total stand basal area and $H$ is the aver- 
Table 8. Diameter Class Oven-dry Weight Estimates Using Regression Models 8 and $9^{1}$

\section{Average ODWT Estimates}

\begin{tabular}{cccccc}
$\begin{array}{l}\text { Diameter } \\
\text { Class }\end{array}$ & $\begin{array}{c}\text { Average } \\
\text { Actual } \\
\text { ODWT }\end{array}$ & $\begin{array}{c}\text { Equation } 8 \\
\text { using(D) }\end{array}$ & $\begin{array}{c}\text { Percent } \\
\text { of Actual }\end{array}$ & $\begin{array}{c}\text { Equation 9 } \\
\text { using(BH) }\end{array}$ & $\begin{array}{c}\text { Percent } \\
\text { of Actual }\end{array}$ \\
\hline cm & $\mathrm{kg}$ & $\mathrm{kg}$ & $\mathrm{kg}$ & 95 \\
$6.60-8.89$ & 16.7 & 13.1 & 78 & 15.8 & 101 \\
$9.14-11.43$ & 32.1 & 27.7 & 86 & 32.5 & 106 \\
$11.68-13.97$ & 50.1 & 49.6 & 99 & 53.1 & 102 \\
$14.22-16.51$ & 82.8 & 79.7 & 96 & 84.7 & 100 \\
$16.76-19.05$ & 132.2 & 119.0 & 90 & .132 .2 & 96 \\
$19.30-21.59$ & 180.6 & 168.5 & 93 & 173.3 & 105 \\
$21.84-24.13$ & 222.8 & 228.9 & 103 & 234.6 & 95 \\
$24.38-26.67$ & 311.2 & 301.2 & 97 & 293.3 & 103 \\
$26.92-29.21$ & 351.2 & 385.9 & 110 & 363.7 &
\end{tabular}

1 Estimates include all sample trees of each species from all study areas. Regression Models are as follows:
(8) $\operatorname{Ln}($ ODWT $)=.28603+2.60319 \mathrm{Ln}$
(D) $\mathrm{R}^{2}=.99$
(9) $\operatorname{Ln}(\mathrm{ODWT})=2.39230+.97555 \mathrm{Ln}(\mathrm{BH}) \mathrm{R}^{2}=.99$

2 The difference between actual yield and estimated yield expressed as a percentage of actual yield. 
age weighted height of all trees in the stand (each tree was weighted by its squared diameter), were found to effectively predict stand biomass in $\mathrm{kg} / \mathrm{ha}$ (ODWT). Equations are as follows :

$$
\begin{gathered}
\operatorname{In}(\text { ODWT })=-1.73061+1.22733 \operatorname{Ln}(B H) \\
R^{2}=.91 \\
\operatorname{In}(O D W T)=1.14376+1.61363 \operatorname{Ln}(B) \\
R^{2}=.88
\end{gathered}
$$

Table 9 illustrates the reliability of using the regression models to estimate biomass production for individual study areas. Both equations 10 and 11 predicted actual yields with about the same accuracy. Equation 10 using $(\mathrm{BH})$ and equation 11 using (B) estimated stand biomass within an average of 5 and 4 percent, respectively, of actual yields. This being the case, equation 11 seems a logical choice for obtaining quick, accurate estimates of cordwood biomass from hardwood stands on moderately well-drained sites in Rhode Island. In mixed-oak stands similar to those found in Rhode Island, Wiant and Charleton (1978) in northern west Virginia developed two rapidweight estimation equations using basal area 
Table 9. Estimates of Oven-dry Weight Biomass ( $\mathrm{kg} / \mathrm{ha}$ ) by study Area Using Regression Models 10 and $11^{1}$

ODWT Estimates

$\begin{array}{ccccc}\text { Actual Equation } 10 & \text { Percent } & \text { Equation } 11 & \text { Percent } \\ \text { Study Area } & \text { ODWT } & \text { using(BH) } & \text { of Actual } & \text { using(B) } \\ \text { of Actual }\end{array}$

Great Swamp I

$\begin{array}{lrrrrr}\text { Plot 1 } & 114000 & 105050 & 92 & 103750 & 91 \\ \text { Plot 2 } & 117825 & 119775 & 102 & 126125 & 107\end{array}$

Great Swamp II

$\begin{array}{rrrrrr}\text { Plot 1 } & 78725 & 78725 & 100 & 81450 & 103 \\ \text { P1ot 2 } & 108650 & 108975 & 100 & 109775 & 101\end{array}$

Hazard Tract

$\begin{array}{lrrrrr}\text { Plot 1 } & 121675 & 119625 & 98 & 117850 & 97 \\ \text { Plot 2 } & 98450 & 106200 & 108 & 99975 & 101\end{array}$

1 Regression models. are as follows:

(10) $\operatorname{Ln}($ ODWT $)=1.73061+1.22733 \operatorname{Ln}(\mathrm{BH}) \quad \mathbf{R}^{2}=.91$
(11) $\operatorname{Ln}($ ODWT $)=1.14376+1.61363 \mathrm{Ln}(\mathrm{B}) \quad \mathbf{R}^{2}=.88$

2 The difference between actual yield and estimated yield expressed as a percentage of actual yield. 
per acre (B) and average stand height (H) in feet. The equations are as follows:

$$
\begin{aligned}
(.94)(B)= & (O D W T) \text { in thousand pounds } \\
& \text { per acre } \\
(1.72)(H)= & (O D W T) \text { in thous and pounds } \\
& \text { per acre }
\end{aligned}
$$

These equations were used to estimate biomass from the study areas. Equation 12 estimated biomass within about 3 percent of actual values and equation 13 within 4 percent. Equations appear to describe biomass production for the study sites very well. In fact, equations 12 and 13 are as effective as equations 10 and 11 developed from stand data. This indicates close similarity of biomass production in West Virginia and Rhode Island and probably for the entire oak region in the Northeast. Incorporation of data from additional stands and a variety of sites would be advisable to see if relationships are valid under varied site conditions.

\section{Site Comparisons}

a. Yield Comparisons

Cordwood production values for the three study areas as already indicated are very similar: 
approximately 73 cords per hectare $(30$ cords per acre). However, meain annual cordwood increment differs for each stand ranging from 1.3 cords to 2.3 cords per hectare $(.54$ cords to .94 cords per acre). Cordwood production values for the stands studied were compared to yield tables for fully-stocked, even-aged, second-growth, Appalachian hardwood stands developea by Schnur (1937) (see Table 10).

Schnur's yield tables are based on site index and on yields of material greater than $10.1 \mathrm{~cm}$ (4 incies) dob. For purposes of comparison, stand yields were compared with Schnur's yields for sites with similar site indices. In addition, since cordwood yields for the study stands were based upon yields for stems greater than $2.5 \mathrm{~cm}$ doj, it was necessary to adjust values to include only material greater than $10.1 \mathrm{~cm}$ doj. Recorded data from sample trees indicated that an average of 11.5 percent of the biomass of sample trees was accounted for by material from $2.5 \mathrm{~cm}$ to $5.1 \mathrm{~cm}$ in diameter. Thus, it was estimated that about 34.5 percent of total tree weigit would be included in the diameter range from $2.5 \mathrm{~cm}$ to $10.1 \mathrm{~cm}$. Stand cordwood yields were reduced by this amount. 
TABLE 10. Production Yields of Even-aged, Second-growth Hardwoods by Study Area Compared to Schnur's Yield Tables

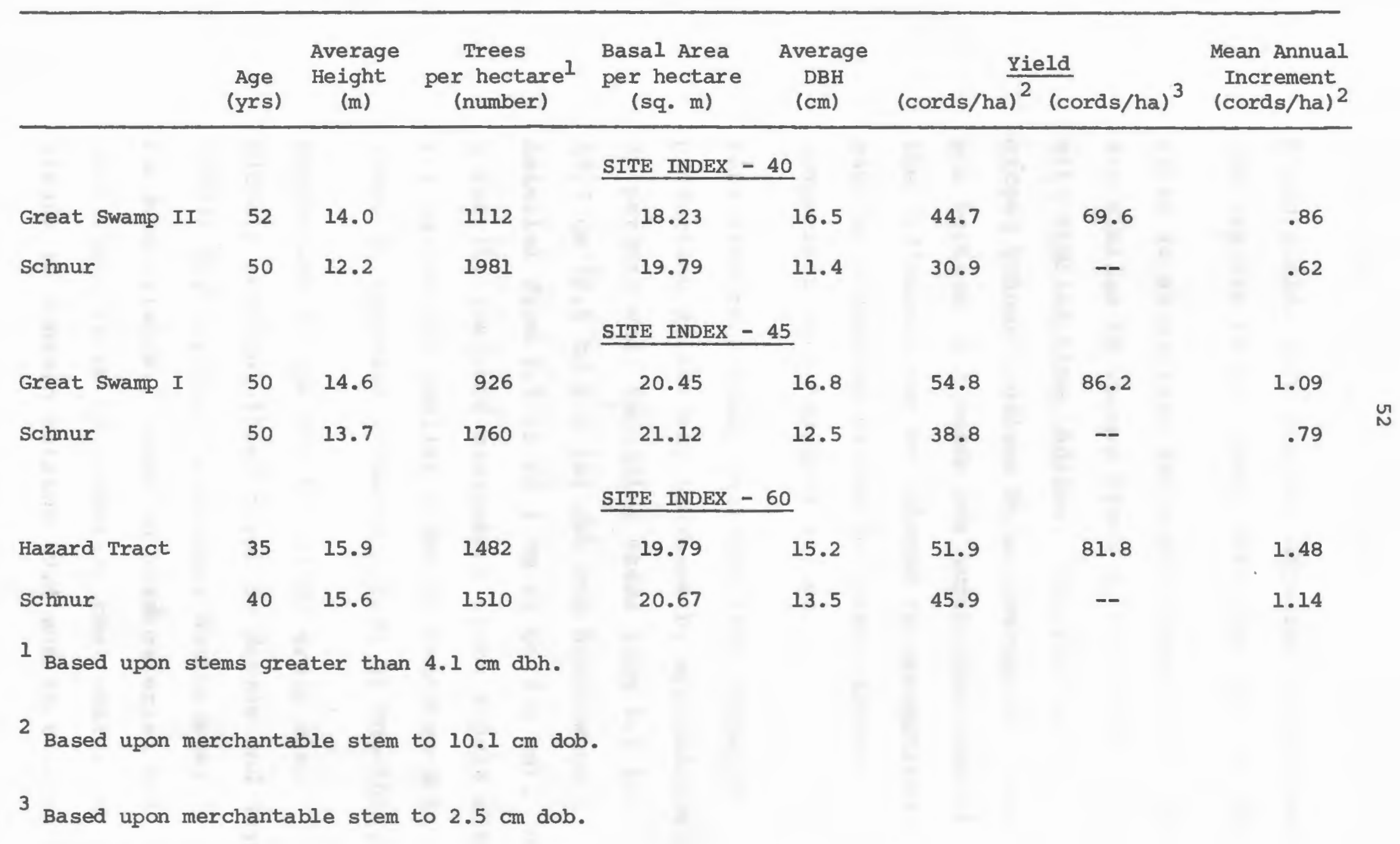


Stand yields were further adjusted by subtracting weights of all stems less than $12.7 \mathrm{~cm}$ dbh. Table 10 shows that adjusted production yields are similar to values given by Schnur for sites with similar site indices. Adjusted yields exceed Schnur's values by an average 10.6 cords per hectare ( 4.3 coras per acre), but some of the difference may be related to assumptions made in adjusting values to permit direct comparison with schnur's values.

Data from this study indicate that cordwood production yields may increase by approximately 36 percent when including stems from 6.6 to $12.7 \mathrm{~cm}(2.6$ to $5.0 \mathrm{in}) \mathrm{dbh}$ and branchwood material from 2.5 to $10.1 \mathrm{~cm}$ ( 1 to $4.0 \mathrm{in}$ ). As a result, fuelwood management plans should allow for harvesting smaller diameter branchwood in order to increase cordwood yields by one-third.

Production values for the study areas also closely parallel those given by Morrow and Gage (1977) for typical, unmanaged, Nortneastern hardwood stands. Based on stem material not less than $7.6 \mathrm{~cm}$ in diameter, they estimated stands to contain between 49.4 and 98.8 cords 
per hectare with growth occurring at an average rate of 1.2 cords per hectare.

Wiant and Castaneda (1978) investigated oak forest biomass production in northwestern West Virginia. They developed yield tables based upon stand tables published by Schnur (1937) and regression estimation equations developed by wiant et al. (1977). Wiant and Castaneda indicate that their yield tables (based upon stemwood greater than $5.1 \mathrm{~cm}$ dob) should prove applicable in even-aged, Eastern oak forests. In fact, their yield tables closely approximate measured yields for the study areas. Estimated yields for Great Swamp I and Great Swamp II were within 6 and 8 percent of actual yields, and within 1 percent of the actual yield for the Hazard Tract.

b. Soil-Productivity Relationships

Soil properties were evaluated in an effort to relate differences in site productivity to soil characteristics. Soil properties for the $A$ and $B$ horizons on each study site are given in Table 11 .

Although soil-related variables were not significant in explaining differences in wood pro- 
TABLE 11. Average Soil Properties for A and B Horizons on the Study Sites

\begin{tabular}{|c|c|c|c|c|c|c|c|c|}
\hline study site & Horizon & $\begin{array}{c}\text { Texture } \\
(\% \text { silt }+ \text { clay })\end{array}$ & $\begin{array}{l}\text { Organic } \\
\text { Carbon }(8)\end{array}$ & $\begin{array}{l}\text { Available } \\
\text { Water (z) }\end{array}$ & $\begin{array}{l}\text { Bulk Density } \\
(g / c c)\end{array}$ & $\begin{array}{l}\mathrm{pH} \\
1: 1 \\
\mathrm{H}_{2} \mathrm{O}\end{array}$ & $\begin{array}{l}\text { Depth } \\
(\mathrm{cm})\end{array}$ & $\begin{array}{c}\text { Coarse } \\
\text { Fragments ( }) \text { ) }\end{array}$ \\
\hline
\end{tabular}

Great Swamp I

Plot 1

Plot 2

$$
23.4
$$

$$
12.2
$$

19.7

13.0

$\begin{array}{ll}\text { A } & 19.7 \\ \text { B } & 13.0\end{array}$

1.41

.20

1.49

.27

Great swamp II

plot 1

Plot 2

Hazard Tract

Plot 1

B

Plot 2

\section{A}

A

B
51.6

41.3

48.5

42.3

$\begin{array}{ll}9.8 & 1.28 \\ 5.5 & 1.51 \\ 6.4 & 1.32 \\ 4.7 & 1.49\end{array}$

$\begin{array}{ll}4.75 & 18 \\ 4.81 & 74 \\ 4.68 & 18 \\ 4.75 & 71\end{array}$

.7

.6

.9

.5

$\begin{array}{rrrrrr}4.62 & 13.5 & 1.02 & 4.40 & 15 & 2.3 \\ .52 & 9.0 & 1.50 & 4.54 & 56 & 4.7 \\ 5.16 & 11.2 & 1.09 & 4.35 & 13 & 3.1 \\ .55 & 8.6 & 1.44 & 4.58 & 53 & 7.8\end{array}$


duction on a tree or unit area basis in regression analyses, other analyses indicate correlations between tree-growth parameters and soil characteristics. Principal component analysis was conducted on a variable matrix including tree, soil and stand characteristics. This permitted an examination of linear combinations between all variables. Soil variables highly correlated with tree-growth (productivity related) parameters including $\mathrm{dbh}$, height and weight were: soil texture, organic carbon, available water and depth of solum. Soil bulk density, pH, depth of the A horizon and coarse fragment content were not significantly correlated with tree-growth parameters.

In addition to principal component analysis, a canonical variate analysis was conducted to develop a single correlation between two sets of variables; biotic tree-growth parameters and soil characteristics. Despite an extremely high correlation (.97) between $d b h$ and weight with soil texture, organic carbon, available water and depth of solum, sample size was insufficient to permit the development of meaningful equations for determining site productivity. 
An examination of soil properties and yields for the plots sampled, reveals inconsistencies in relationships between soils and yields. For example, the Hazard Tract site and the Great Swamp II site have similar soil conditions but yields are much different. Both sites have soil characteristics typically associated with optimal tree growth. The Hazard Tract is the most productive site and Great Swamp II is the least productive. Apparently, factors other than edaphic must be limiting tree growth on the Great Swamp II site. The major difference between sites is the presence of a dense ericaceous shrub understory at Great Swamp II. Competition for water and nutrients may account for differences in productivity.

Inconclusive findings, as to the significance of soil-productivity relationships, indicate the need to sample additional areas and to expand sampling to include all drainage classes. Biological considerations may overshadow soil conditions to the point where the development of meaningful soil-site productivity relationships may not be possible. 
Interpretation tables for Rhode Island soils, compiled by the U.S. Soil Conservation Service (U.S.D.A., 1975b), contain average site indices for hardwoods and softwoods growing on different soil series. The site index given for the Scio silt loam soil at the Hazard Tract site is 62 for hardwoods: similar to the actual value of 60. However, soils at the Great Swamp study areas would also indicate site indices of about 60 , but actually have site indices of only about 40. Thus, it appears that site index varies considerably on soils of the same drainage class that are considered similar in terms of their abilities to grow trees.

Although based on limited data, tree and stand heights in this study do not appear to work well in indexing site productivity, since height was not significantly correlated with biomass or site factors. Similarly, McGahan et al. (1961) found tree height in Rhode Island mixedoak stands was extremely variable and not strongly correlated with edaphic and stand characteristics. Consequently, height as an index of site productivity, for mixed-oak for the Rhode Island area, appears to be of questionable value. Therefore, further study 
relating soil properties and wood production is warranted. 


\section{SUMMARY AND CONCLUSIONS}

The study was conducted in three mixed-hardwood stands located in Washington County in the town of South Kingstown, Rhode Island: one on the University of Rhode Island Hazard Tract and two on the Great Swamp Wildlife Management Area. Even-aged, sprout-origin forest stands on the study sites were either mixed-oak or red maple which are two of the most common forest types in Rhode Island.

Moderately well-drained soils served as the basis for selection of study areas. Each study area was located on a different soil type so as to relate variation in wood production to soil characteristics. Soil types included Scio silt loam at the Hazard Tract, and Birchwood loamy sand, Woodbridge sandy loam and Sutton sandy loam at the Great Swamp study sites.

Tree characteristics including species, dbh, total tree height, height to live crown, crown class and age were recorded for each stem greater than $4.1 \mathrm{~cm}$ dbh. To ensure representative and reliable estimates of above-ground biomass, stratified random sampling of trees by diameter class was used to select sample trees. A total of 93 stems representing seven hardwood species was destructively sampled on the study sites.

Sample trees were felled, sectioned and separated into two components: stemwood and branchwood. Total green weight by component was recorded for each tree in the field. Com- 
ponents were subsampled to permit oven-dry weight and specific gravity determinations. Following determination of green disk volume by water displacement, samples were placed in drying ovens to determine moisture content. Specific gravity was determined for each sample based upon green volume and oven-dry weight. Values based upon subsamples were used to project fuelwood production per unit area on a weight and volume basis for each study area. Mean radial growth and growth rate curves for codominant and dominant trees on each study area were determined from sample sections taken at stump height.

Several physical and chemical soil properties were evaluated on the study sites. Properties measured were; bulk density, particle size, organic carbon, percent moisture at field capacity, percent moisture at wilting point, pH, cation exchange capacity, exchangeable acidity and percent base saturation. Also, nutrient concentrations were determined using a spectrophotometer.

Regression analyses were employed to develop equations to estimate fuelwood biomass. Principal component and canonical correlation analyses were used to evaluate relationships between tree-growth parameters and soil characteristics. Analyses were performed on the University of Rhode Island I.B.M. System 370 computer. 
Results may be concluded as follows:

1. Average specific gravity for black oak. (.63) was found to be significantly higher than averages for white oak (.61) and red maple (.55) at the .05 and .01 levels, respectively. Also, white oak was found to differ significantly from red maple at the .05 level. An examination of specific gravities for ring-porous and diffuse-porous hardwoods showed no relationship with growth rate.

2. Mean radial increment for the study areas based upon dominant and codominant trees was markedly different between study areas. Radial increment was greatest on the Hazard Tract ( $3.48 \mathrm{~mm}$ per year) in contrast to the Great Swamp sites where mean radial increment was 2.63 on one site and 2.15 on the other. Radial growth rate curves for the Great Swamp study sites began to level off as average stand age approached 50 years. There was no indication of radial growth leveling off in the 35-year-old Hazard Tract stand.

3. Data from the three study areas were pooled to obtain an estimate of fuelwood production for moderately welldrained sites. Pooled data indicated a total yield of 73 cords per hectare (30 cords per acre) at age 45 , and a mean annual increment of 1.6 cords per hectare $(.65$ cords per acre). Cordwood yields were based upon including branchwood material down to. $2.5 \mathrm{~cm}$ in diameter. 
4. Recorded data from sample trees indicated that an average of 11.5 percent of tree biomass was accounted for by material from $2.5 \mathrm{~cm}$ to $5.1 \mathrm{~cm}$ in diameter. Thus, it was estimated that about 34.5 percent of total tree weight would be included in the diameter range from 2.5 to $10.1 \mathrm{~cm}$. By including stems from 6.6 to $12.7 \mathrm{~cm}$ $(2.6$ to $5.0 \mathrm{in}) \mathrm{dbh}$ and branchwood from 2.5 to $10.1 \mathrm{~cm}$ (1 to 4.0 in) dob, cordwood yields from the study sites increased by approximately 36 percent.

5. Regression analyses indicated that dbh accounted for most of the variation in whole-tree weight. Allometric regression equations, combining data from all study areas, were developed in order to estimate green (GWT) and oven-dry weight (ODWT) of individual trees and stand biomass.

a. Data were pooled to develop regression equations to estimate whole-tree weight as a function of (DBH); and as a function of the combined variable (BH) where (B) is tree basal area and (H) is tree height. Equations are as follows:

$$
\begin{array}{ll}
\operatorname{Ln}(\mathrm{ODWT})=-.39986+2.65919 \mathrm{Ln}(\mathrm{DBH}) & \mathrm{R}^{2}=.95 \\
\operatorname{Ln}(\mathrm{GWT})=.11714+2.66262 \mathrm{Ln}(\mathrm{DBH}) & \mathrm{R}^{2}=.94 \\
\mathrm{Ln}(\mathrm{ODWT})=2.35524+.99342 \mathrm{Ln}(\mathrm{BH}) & \mathrm{R}^{2}=.97 \\
\operatorname{Ln}(\mathrm{GWT})=2.87187+.99550 \mathrm{Ln}(\mathrm{BH}) & \mathrm{R}^{2}=.97
\end{array}
$$


b. Equations were also developed to predict cordwood biomass on a unit area basis. In the following equations, stand basal area $(\mathrm{B})$ and $(\mathrm{BH})$, where (B) is total stand basal area and $(H)$ is the average weighted height of all trees in the stand (each tree weighted by its squared diameter), were found to effectively predict stand biomass.

$$
\begin{array}{lll}
\operatorname{Ln}(\text { ODWT })=-1.73061+1.22733 \operatorname{Ln}(\mathrm{BH}) & \mathrm{R}^{2}=.91 \\
\operatorname{Ln}(\mathrm{ODWT})=1.14376+1.61363 \mathrm{Ln}(\mathrm{B}) & \mathrm{R}^{2}=.88
\end{array}
$$

6. Cordwood production values for the study areas closely paralleled those given by Schnur (1937), Morrow and Gage (1977) and Wiant and Castaneda (1978) for fullystocked, even-aged, second-growth, Appalachian hardwood stands.

7. Soil properties were evaluated in an effort to relate differences in site productivity to soil characteristics. Soil variables highly correlated with tree-growth parameters including $d b h$, height and weight were: soil texture, organic carbon, available water and depth of solum. However, sample size was insufficient to permit the development of meaningful equations for determining site productivity.

Inconclusive findings as to the significance of soilproductivity relationships indicate the need to sample additional areas and to expand sampling to include all 
drainage classes. However, as indicated in this study, biological considerations may overshadow soil conditions to the point where the development of meaningful soilsite productivity relationships may not be possible.

8. Although based on limited data, tree and stand heights in this study did not appear to work well in indexing site productivity. Site index was found to vary considerably on soils of the same drainage class that are considered similar in terms of their abilities to grow trees. As a result, height as an index of site productivity for mixed-oak stands in the Rhode Island area appears to be of questionable value. 
REFERENCES CITED

Art, T. R. and P. L. Marks. 1971. A summary table of biomass and net annual primary production in forest ecosystems of the world. p. 3-32. In Forest biomass studies. Univ. Me. Life Sci. and Agri. Expt. Sta. Misc. Publ. 132. Orono, Me. 240 p. Baskerville, G. L. 1965. Estimation of dry weight of tree components and total standing crop in conifer stands. Ecol. $46: 867-869$.

Black, C. A., ed. 1965. Methods of Soil Analysis. Amer. Soc. Agron. Inc. Madison, Wisc. 1572 p. Brown, J. H., Jr. 1960. The role of fire in altering species composition of forests in Rhode Island. Ecol. $41(2): 310-316$. Clark, A. III and M. A. Taras. 1976. Comparison of aboveground biomasses of the four major southern pines. For. Prod. J. 26(10):25-29.

Cox, D. R. 1961. Tests of separate families of hypotheses. 4th Berkeley Symp. Proc. 1:101-123.

Crow, T. R. 1971. Estimination of biomass in an even-aged stand -- regression and "mean tree" techniques. Sci. J. Serv. Pap. No. 7487. Univ. Minn. Agri. Expt. Sta., St. Paul, Minn. 13 p. Dalton, M. M., J. H. Herrington, O. B. Durgin and R. A. Andrews. 1977. Household fuelwood use and procurement in New Hampshire. Univ. N. H. Agri. Expt. Sta. 
Rpt. No. 59. Durham, N. H. 24 p. Fernald, L. M. 1950. Gray's Manual of Botany. Amer. Book Co. N. Y. 1632 p.

Forbes, R. D. 1955. Forestry Handbook. Ronald Press Co. N. Y. $1137 \mathrm{p}$.

Freese, F. 1967. Elementary statistical methods for foresters. U.S.D.A. For. Serv. Agri. Handb. 317. U.S. Govt. Printing Office. Washington, D.C. 87 p. Furnival, G. M. 1961. An index for comparing equations used in constructing volume tables. For. Sci. $7: 337-341$.

Green, D. C. and D. F. Grigal. 1978. Generalized biomass estimation equations for jack pine (Pinus banksiana Lamb.). Sci. J. Serv. Pap. No. 1698. Univ. Minn. Agri. Expt. Sta., St. Paul, Minn. 4 p. Harris, B. K. and T. E. Odland. 1948. Rhode Island weather. Univ. R. I. Agri. Expt. Sta. Bull. No. 299. Kingston, R. I. 32 p.

Haush, B., C. I. Miller and T. W. Beers. 1972. Forest Mensuration. Second edition. Ronald Press Co. N. Y. 410 p.

Johnston, R.S. and D. L. Bartos. 1977. Summary of nutrient and biomass data from two aspen sites in western United States. U.S.D.A. For. Serv. Res. Pap. INT-227. Interm. For. and Range Expt. Sta., Ogden, Utah. 15 p. 
Johnstone, W. D. 1971. Total standing crop and tree component distributions in three stands of 100-yearold lodge pole pine. p. 81-89. In Forest biomass studies. Univ. Me. Life Sci. and Agri. Expt. Sta. Misc. Publ. 132. Orono, Me. 240 p.

Keays, J. L. 1971. Complete-tree utilization: an analysis of the literature. Can. For. Serv. For. Prod. Lab. Info. Rpt. VP-X-71. Vancouver, B.C. 67 p. Keen, R. E. 1963. Weights and centres of gravity involved in handling pulpwood trees. Pulp Pap. Res. Inst. Can., Woodlands Res. Index No. 147. 93 p. Madgwick, H. A. I. 1971. The accuracy and precision of estimates of the dry matter in stems, branches, and foliage in an old-field Pinus virginiana stand. p. 105-109. In Forest biomass studies. Univ. Me. Life Sci. and Agri. Expt. Sta. Misc. Publ. 132. Orono, Me. $240 \mathrm{p}$.

McGahan, M. W. J. H. Brown, Jr., W. P. Gould, H. C. Lampe and A. E. Shearin. 1961. Site conditions and tree growth analyses in Rhode Island forests. Univ. R. I. Agri. Expt. Sta. Bull. 357. Kingston, R. I. 32 p. Morrow, R. R. and T. E. Gage. 1977. The use of wood for fuel. Cornel1 univ. Cons. Circ. 15(1):1-11. NOAA. 1974. Annual summary of climatological data. U.S. Dept. Comm. Nat. Climatic Cent. Asheville, N.C. Ovington, J. D. 1962. Quantitative ecology and the woodland concept. Adv. Ecol. Res. 1:103-192. 
Ovington, J. D., W. G. Forrest and J. E. Armstrong. 1967. Tree biomass estimation. p. 4-31. In Primary productivity and mineral cycling in natural ecosystems. Ecol. Soc. Amer. and AASS. Univ. Me. Press. Orono, Me. Panshin, A. J. and C. DeZeeuw. 1970. Textbook of Wood Technology. Volume 1. Third edition. McGraw-Hill Book Co. N. Y. 705 p.

Paul, B. H. 1930. The application of silviculture in controlling specific gravity. U.S.D.A. Tech. Bull. No. 168. U. S. Govt. Printing Office. Washington, D.C.

Pulp and Paper Association of Canada. 1928. Report of the wood measurement committee. Pulp Pap. Mag. Can., Int. No. 139-149.

Roth, E. R. and G. H. Hepting. 1943. Origin and development of oak stump sprouts as affecting their likelihood to decay. J. For. 41:27-36.

Schlaegel, B. E. 1975. Estimating aspen volume and weight for individaul trees, diameter classes, or entire stands. U.S.D.A. For. Serv. Gen. Tech. Rpt. NC-20, North Cent. For. Expt. Sta., St. Paul, Minn. 16 p. Schnur, G. L. 1937. Yield, stand and volume tables for even-aged upland oak forests. U.S.D.A. Tech. Bull. No. 560. U.S. Govt. Printing Office. Washington, D. C. $87 \mathrm{p}$. 
Schreuder, H. T. and W. T. Swank. 1971. A comparison of several statistical models in forest biomass and surface area estimation. p. 125-136. In Forest biomass studies. Univ. Me. Life Sci. and Agri. Expt. Sta. Misc. Publ. 132. Orono, Me. 240 p.

Skeen, J. N. 1973. Biomass and productivity estimates for a temperate mesic slope forest. J. Tenn. Acad. Sci. $48(3): 103-106$.

Smith, D. M. 1962. The Practice of Silviculture. Seventh edition. John Wiley \& Sons, Inc. N.Y. 578 p. Smith, J. H. G. 1967. A procedure for simple definition of land capability for wood growth and for estimation of yield. Dept. For. and Rural Dev., Nat. Comm. For. Land Proc. 126-42.

Smith, J. H. G. 1971. Bases for sampling and simulation in studies of tree and stand weights. p. 139-149. In Forest biomass studies. Univ. Me. Life Sci. and Agri. Expt. Sta. Misc. Publ. 132. Orono, Me. 240 p. Smith, J. H. G., J. W. Kerr and J. Csizmazia. 1961. Economics of reforestation in the Vancouver forest district. Univ. B. C. Fac. For. Bull. No. 3. Vancouver, B.C. 144 p.

Stoddard, W. R. 1979. Estimation of a demand function for household firewood usage in Rhode Island. Unpublished master's thesis. Univ. R. I., Kingston, R. I. 73 p. 
Toumey, J. W. and C. F. Korstian. 1947. Foundation of Silviculture Upon an Ecological Basis. John Wiley and Sons, Inc. N. Y. 468 p.

U.S. Dept. Agri. 1975a. Soil Taxonomy. Soil Cons. Serv. U. S. Govt. Printing office. Washington, D.C. U.S. Dept. Agri. 1975b. Rhode Island Interpretation Tables Soil Cons. Serv. U.S. Govt. Printing office. Washington, D.C. Wartluft, J. L. 1977. Weights of small Appalachian hardwood trees and components. U.S.D.A. For. Serv. Res. Pap. NE-366. NE For. Expt. Sta., Upper Darby, Pa. 4 p. Weetman, G. F. and R. Harland. 1964. Foliage and wood production in unthinned black spruce in northern Quebec. For. Sci. $10(1): 80-88$.

Wells, C. G., J. R. Jorgensen and C. E. Burnette. 1975. Biomass and mineral elements in a thinned loblolly pine plantation at age 16. U.S.D.A. For. Serv. Res. Pap. SE-126. SE For. Expt. Sta., Asheville, N.C. 10 p. Wendel, G. W. 1975. Stump sprout growth and quality of several Appalachian hardwood species after clearcutting. U.S.D.A. For. Serv. Res. Pap. NE-329. NE For. Expt. Sta., Upper Darby, Pa. 9 p.

Whittaker, R. H. and G. M. Woodwell. 1969. Measurement of net primary production of forests. In Conference of forest productivity of the world. Inter. Bio. Prog. Bruxelles, Belgium. 43 p. 
Wiant, H. V., Jr. and F. Castaneda. 1978. Preliminary weight yield tables for even-aged upland oak forests. W. Va. Univ. Agri. and Expt. Sta. Bull. 664T. Morgantown, w. Va. 20 p.

Wiant, H. V., Jr. and P. M. Charleton. 1978. Rapid weight estimations for upland oak stands. W. Va. Univ. Agri. and For. Expt. Sta. $7(3): 12$. Morgantown, w. Va. 18 p. Wiant, H. V., Jr., C. E. Sheetz, A. Colaninno, J. C. DeMoss and F. Castaneda. 1977. Tables and procedures for estimating weights of some Appalachian hardwoods. w. Va. Univ. Agri. and For. Expt. Sta: Bull. 659T. Morgantown, w. Va. $36 \mathrm{p}$.

Young, H. E. 1964. The complete tree concept - a challenge and an opportunity. Proc. 1964 annual meeting of the Soc. Amer. Foresters.

Young, H. E. 1973. Growth, yield and inventory in terms of biomass. p. 1-10. In IUFRO biomass studies, Univ. Me. Life Sci. and Agri. Expt. Sta., Orono, Me. $531 \mathrm{p}$.

Young, H. E., L. Strand and R. Altenberger. 1964. Preliminary fresh and dry weight tables for seven tree species in Maine. Univ. Me. Agri. Expt. Sta. Bull. No. 12. Orono, Me. $76 \mathrm{p}$. 
73

APPENDICES 
APPENDIX A 
Profile Description

of $a$

Birchwood Sandy Loam

(Typic Fragiochrept/Sandy, mixed mesic)

Typifying Pedon: Birchwood sandy loam - forested

Horizon Depth (cm)

02

Ap

$0-18$

B2I

B22

$35-53$

B3g

$53-90$

$\mathrm{Cx}$

$90-110$
Description

Organic layer of decomposed forest litter.

Dark brown (IOYR $3 / 3$, moist) fine sandy loam; weak medium subangular structure breaking to moderate fine granular structure; friable; many medium woody and fibrous roots; strongly acid; abrupt smooth boundary.

Yellow-brown (10YR 5/6, moist) fine sandy loam; weak medium subangular blocky structure; friable; many medium woody roots; strongly acid; gradual wavy boundary.

Light olive-brown ( $2.5 \mathrm{Y} 5 / 6$, moist) sandy loam; weak medium subangular blocky structure breaking to moderate fine granular structure; very friable; common fine woody roots; strongly acid; clear wavy boundary.

Light olive-gray ( $5 \mathrm{Y} 6 / 2$, moist) loamy sand; weak medium subangular blocky structure breaking to moderate fine granular structure; very friable; few fine woody roots; many medium prominent reddish-yellow (7.5YR 6/8, moist) mottles; strongly acid; abrupt smooth boundary.

Light yellowish-brown (2.5Y $6 / 4$, moist) gravelly sand; structureless massive; firm; many coarse fragments; strongly acid. 


\section{Site Characteristics}

Location: South Kingstown, Rhode Island; Great Swamp I Area, plot 1

Parent Material: Glacial till

Topography: Gently sloping

Slope and Aspect: 2 percent; east

Elevation: 36 meters

Drainage and Permeability: Moderately well-drained; rapid

Available water holding capacity: Low

Ground Water: Deep; not observed during description

Vegetation: Mixed-oak forest/sparse shrub layer

Root Distribution: Many roots to $\mathrm{B} 3 \mathrm{~g}$ horizon

Erosion: Slight

Stoniness: Stony

Date: September 19, 1978

Described by: Jeffrey A. Bridge 
Profile Description

of a

Birchwood Sandy Loam

(Typic Fragiochrept/Sandy, mixed mesic)

Typifying Pedon: Birchwood very stony sandy loam - forested

Horizon Depth $(\mathrm{cm})$

Description

02

3-0

Organic layer of decomposed forest litter.

Ap $\quad 0-18$

Dark brown (10YR 3/3, moist) fine sandy loam; weak medium subangular blocky structure breaking to moderate fine granular structure; very friable; many medium woody and fibrous roots; strongly acid; abrupt smooth boundary.

B21 $18-48$

B22

$48-73$

B3 $73-88$

Yellowish-brown (10YR 5/8, moist) sandy loam; weak medium subangular blocky structure; very friable; many medium woody roots; strongly acid; clear wavy boundary.

Yellowish-brown (1OYR 5/6, moist) sandy loam; weak medium subangular blocky structure breaking to moderate fine granular structure; very friable; common fine woody roots; layer of many large coarse fragments strongly acid; clear wavy boundary.

\section{B3}

$\mathrm{Cx}$

$88-105$

olive-yellow (2.5Y $6 / 6$, moist) loamy sand; structureless, single grain; loose; few medium faint yellowishbrown (IOYR 5/8, moist) mottles; strongly acid; abrupt smooth boundary.

Light brownish-gray (IOYR $6 / 1$, moist) gravelly sand; structureless, massive, firm; many coarse fragments; strongly acid. 


\section{Site Characteristics}

Location: South Kingstown, Rhode Island; Great Swamp I Area, plot 2

Parent Material: Glacial till

Topography: Gently sloping

Slope and Aspect: 8 percent; east

Elevation: 36 meters

Drainage and Permeability: Moderately well-drained; rapid

Available Water Holding Capacity: Low

Ground Water: Deep; not observed during description

Vegetation: Mixed-oak forest/sparse shrub layer

Root Distribution: Many roots to $\mathrm{B} 3$ horizon

Erosion: Slight

Stoniness: Very stony

Date: September 19, 1978

Described by: Jeffrey A. Bridge 
Profile Description

of a

Woodbridge Fine Sandy Loam

(Typic Fragiochrept/Coarse-loamy, mixed mesic)

Typifying Pedon: Woodbridge fine sandy loam - forested

Horizon Depth (cm)

Description

02

5-0

Organic layer of decomposed forest litter.

Ap $\quad 0-15$

Very dark grayish-brown (10YR $3 / 2$, moist) silt loam; weak medium subangular blocky structure breaking to moderate fine granular structure; friable; many large woody roots; many coarse fragments; strongly acid; abrupt smooth boundary.

B21 15-38

Yellowish-brown (lOYR 5/6, moist) loam; weak medium subangular blocky structure; friable; many large woody roots; many coarse fragments; strongly acid; gradual wavy boundary.

B22 $38-50$

Light yellowish-brown $(2.5 \mathrm{y} 6 / 4$, moist) fine sandy loam; weak medium subangular blocky structure; friable; common medium woody roots; many coarse fragments; strongly acid; clear wavy boundary.

B3g $\quad 50-70$

Pale brown (IOYR 6/3, moist) fine sandy loam; weak medium subangular blocky structure; very friable; few fine woody roots; many large prominent strong brown ( $7.5 \mathrm{YR} 5 / 8$, moist) mottles; many coarse fragments; strongly acid; clear wavy boundary. 
Horizon Depth (cm)

Clg

$70-90$

I ICX

$90-109$
Description

Light brownish-gray $(2.5 \mathrm{Y} 6 / 2$, moist) silt loam; weak medium subangular blocky structure; friable; many large prominent strong brown (7.5YR 5/8, moist) mottles; strongly acid; abrupt smooth boundary.

Light brownish-gray (IOYR 6/2, moist) sand; structureless, massive; firm; many coarse fragments; strongly acid. 
Site Characteristics

Location: South Kingstown, Rhode Island; Great Swamp II Area, plot 1

Parent Material: Glacial till

Topography: Gently sloping

Slope and Aspect: 2 percent; southeast

Elevation: 30 meters

Drainage and Permeability: Moderately well-drained; moderate

Available Water Holding Capacity: High

Ground Water: Deep; not observed during description

Vegetation: Red maple forest/dense ericaceous shrub layer

Root Distribution: Many dense roots to $\mathrm{B} 3 \mathrm{~g}$ horizon

Erosion: Slight

Stoniness: Stony

Date: September 25, 1978

Described by: Jeffrey A. Bridge 
Profile Description

of $a$

Sutton Fine Sandy Loam

(Umbric Dystrochrept/Coarse-loamy, mixed mesic)

Typifying Pedon: Sutton very stony fine sandy loam forested

\begin{tabular}{|c|c|c|}
\hline Horizon & Depth (cm) & Description \\
\hline 02 & $5-0$ & $\begin{array}{l}\text { Organic layer of decomposed forest } \\
\text { litter. }\end{array}$ \\
\hline Ap & $0-13$ & $\begin{array}{l}\text { Very dark grayish-brown ( } 10 Y \mathrm{R} 3 / 2 \text {, } \\
\text { moist) silt loam; weak medium sub- } \\
\text { angular blocky structure breaking } \\
\text { to moderate fine granular structure; } \\
\text { friable; many large woody roots; } \\
\text { many coarse fragments; strongly } \\
\text { acid; abrupt smooth boundary. }\end{array}$ \\
\hline B21 & $13-35$ & $\begin{array}{l}\text { Yellowish-brown ( } 10 \text { Y } 5 / 6 \text {, moist) } \\
\text { silt loam; weak medium subangular } \\
\text { blocky structure; friable; many } \\
\text { medium woody roots; many coarse } \\
\text { fragments; strongly acid; gradual } \\
\text { wavy boundary. }\end{array}$ \\
\hline B22 & $35-53$ & $\begin{array}{l}\text { Light yellowish-brown }(2.5 \mathrm{Y} 6 / 4 \text {, } \\
\text { moist) fine sandy loam; weak medium } \\
\text { subangular blocky structure; fri- } \\
\text { able; many medium woody roots; } \\
\text { common organic stains }(2-20 \%) \text { many } \\
\text { coarse fragments; strongly acidi } \\
\text { clear wavy boundary. }\end{array}$ \\
\hline B3 & $53-65$ & $\begin{array}{l}\text { Light yellowish-brown }(2.5 Y \text { Y } 6 / 4 \text {, } \\
\text { moist) fine sandy loam; weak medium } \\
\text { subangular blocky structure; fri- } \\
\text { able; few fine woody roots; many } \\
\text { medium distinct strong brown } \\
\text { ( } 7.5 \text { Y } 5 / 8 \text {, moist) mottles; strongly } \\
\text { acid; clear wavy boundary. }\end{array}$ \\
\hline
\end{tabular}


Horizon Depth $(\mathrm{cm})$

Description

\begin{tabular}{|c|c|c|}
\hline $\mathrm{Clg}$ & $65-123$ & $\begin{array}{l}\text { Light brownish-gray }(2.5 Y \text { Y } 6 / 2 \text {, } \\
\text { moist) silt loam; structureless, } \\
\text { massive; friable; many large promi- } \\
\text { nent strong brown ( } 7.5 \text { Y } 5 / 8 \text {, } \\
\text { moist) mottles; strongly acid; } \\
\text { clear wavy boundary. }\end{array}$ \\
\hline IICX & $123-138$ & $\begin{array}{l}\text { Light brownish-gray }(2.5 y \text { y } 6 / 2 \text {, } \\
\text { moist) gravelly sand; structureless, } \\
\text { massive; firm; many coarse frag- } \\
\text { ments; strongly acid. }\end{array}$ \\
\hline
\end{tabular}




\section{Site Characteristics}

Location: South Kingstown, Rhode Island; Great Swamp II Area, plot 2

Parent Material: Glacial till

Topography: Gently sloping

Slope and Aspect: 2 percent; southeast

Elevation: 30 meters

Drainage and Permeability: Moderately well-drained; moderate

Available Water Holding Capacity: High

Ground Water: Deep; not observed during description

Vegetation: Red maple forest/dense ericaceous shrub layer

Root Distribution: Many dense roots to В3 horizon

Erosion: Slight

Stoniness: Very stony

Date: September 25, 1978

Described by: Jeffrey A. Bridge 
Profile Description

of a

Scio Silt Loam

(Umbric Dystrochrept/Coarse-silty, mixed mesic)

Typifying Pedon: Scio very stony silt loam - forested

Horizon Depth (cm)

$\begin{array}{ll}02 & 3-0 \\ \text { Ap } & 0-15\end{array}$

B21 $15-28$

B22

$28-43$

B23

$43-63$

B39 63-81
Description

Organic layer of decomposed forest litter.

Black (IOYR 2/1, moist) silt loam; weak medium subangular blocky structure breaking to moderate fine granular structure; friable; many medium woody and fibrous roots; many large coarse fragments; strongly acid; abrupt smooth boundary.

Dark brown (IOYR 3/3, moist) silt loam; weak medium subangular blocky structure; friable; common medium woody roots; many large coarse fragments; strongly acid; clear wavy boundary.

Olive brown (2.5Y 4/4, moist) silt loam; weak medium subangular blocky structure; friable; common fine woody roots; strongly acid; clear wavy boundary.

Olive ( $5 Y$ 5/3, moist) silt loam; weak medium subangular blocky structure; friable; few fine woody roots: many coarse fragments: common organic stains $(2-20 \%)$; strongly acid; gradual wavy boundary.

Gray (5Y 6/1, moist) silt loam; weak coarse subangular blocky structure; friable; few fine woody roots; many coarse fragments; many medium distinct yellow (2.5Y $7 / 6$, moist) mottles; strongly acid; clear wavy boundary. 
Horizon Depth $(\mathrm{cm})$

$\mathrm{Clg}$

81-109

IIC2
Description

Gray (5Y 6/1, moist) silt loam; structureless; massive; friable; many medium prominent reddishyellow (7.5YR 6/8, moist) mottles; strongly acid; abrupt smooth boundary.

Strong brown (7.5YR 5/8, moist) fine sand; structureless; single grain; loose; many coarse fragments; strongly acid. 


\section{Site Characteristics}

Location: South Kingstown, Rhode Island; Hazard Tract, plot 1

Parent Material: Glacial outwash

Topography: Gently sloping

Slope and Aspect: 2 percent; northwest

Elevation: 12 meters

Drainage and Permeability: Moderately well-drained; moderate

Available Water Holding Capacity: High

Ground water: $96 \mathrm{~cm}$ when described

Vegetation: Mixed-oak and maple forest/medium shrub layer

Root Distribution: Many roots to $\mathrm{C}$ horizon

Erosion: Slight

Stoniness: Very stony

Date: May 3, 1978

Described by: Jeffrey A. Bridge and William R. Wright 
Profile Description

of a

Scio silt Loam

(Umbric Dystrochrept/Coarse-loamy, mixed mesic)

Typifying Pedon: Scio very stony silt loam - forested

Horizon Depth $(\mathrm{cm})$

02

Ap

$0-15$

B21

$15-45$

B22

B3g

$\mathrm{Clg}$

$84-128$

C2

$128-148$
Description

Organic layer of decomposed forest litter.

Very äark brown (1OYR 2/2, moist) silt loam; medium subangular blocky structure breaking to moderate fine granular structure; friable; many medium woody and fibrous roots; many coarse fragments; strongly acid; abrupt smooth boundary.

Dark brown (7.5YR 4/4, moist) very fine sandy loam; weak medium subangular blocky structure; friable; common medium woody roots; many coarse fragments; strongly acid; clear wavy boundary.

Light olive brown (2.5Y 5/6, moist) silt loam; weak medium subangular structure; friable; few woody roots; many coarse fragments; strongly acid; clear wavy boundary.

Olive ( $5 Y$ 5/3, moist) silt loam; weak medium subangular blocky structure; friable; few medium distinct olive-yellow (2.5Y $6 / 8$, moist) mottles; few woody roots; strongly acid; clear wavy boundary.

Gray (5Y 6/1, moist) silt loam; structureless, massive; friable; many medium prominent reddishyellow (7.5YR 6/8, moist) mottles; strongly acid; gradual wavy boundary.

Brown (10YR 5/3, moist) sand; structureless, single grain; loose; many coarse fragments; strongly acid. 


\section{Site Characteristics}

Location: South Kingstown, Rhode Island; Hazard Tract, plot 2

Parent Material: Glacial outwash

Topography: Gently sloping

Slope and Aspect: 2 percent; east

Elevation: 12 meters

Drainage and Permeability: Moderately well-drained; moderate Available Water Holding Capacity: High

Ground Water: Deep; not observed during description

Vegetation: Mixed-oak and maple forest/medium shrub layer

Root Distribution: Many roots to $\mathrm{C}$ horizon

Erosion: Slight

Stoniness: Very stony

Date: September 19, 1978

Described by: Jeffrey A. Bridge 
90

APPENDIX B 


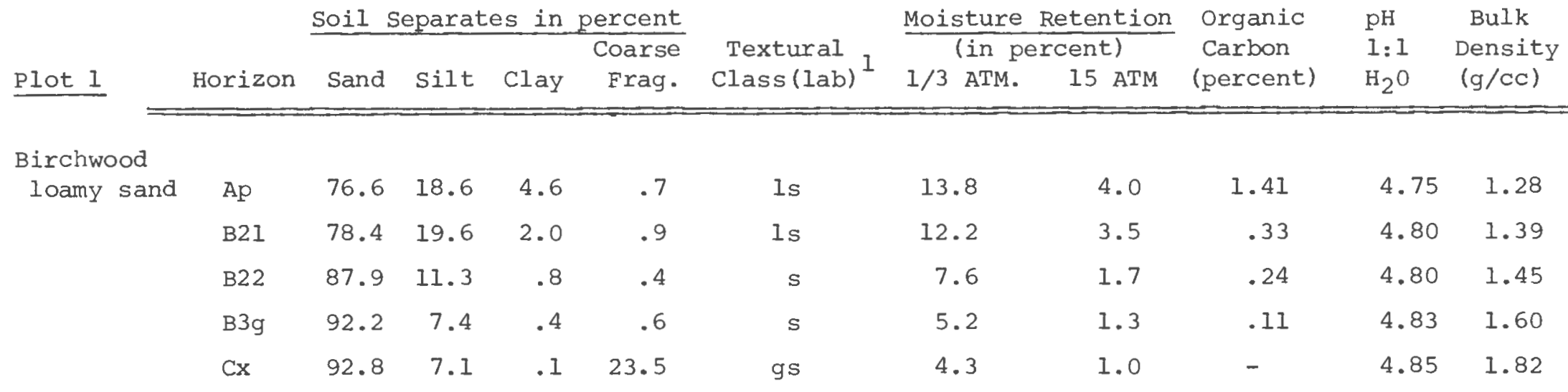

Plot 2

Birchwood

$\begin{array}{lrrrrr}\text { Ap } & 80.3 & 16.2 & 3.5 & .9 & 1 \\ \text { B21 } & 83.6 & 15.4 & 1.0 & .2 & 1 \\ \text { B22 } & 91.2 & 8.4 & .4 & .6 & \\ \text { B3 } & 86.7 & 13.0 & .3 & .8 & \\ \text { Cx } & 82.7 & 17.0 & .3 & 20.4 & 1\end{array}$

Is

Is

s

$\mathrm{S}$

Is
10.5

8.5

5.7

5.9

4.6
4.1

2.5

2.0

1.9

I. I

1 Is-loamy sand; s-sand; gs-gravelly sand. 


\begin{tabular}{|c|c|c|c|c|c|c|c|c|c|c|c|}
\hline \multirow[b]{2}{*}{ Plot 1} & \multirow[b]{2}{*}{ Horizon } & \multicolumn{4}{|c|}{ Soil separates in percent } & \multirow{2}{*}{$\begin{array}{c}\text { Textural } \\
\text { Class (lab) } 1\end{array}$} & \multicolumn{2}{|c|}{$\frac{\text { Moisture Retention }}{\text { (in percent) }}$} & \multirow{2}{*}{$\begin{array}{l}\text { Organic } \\
\text { Carbon } \\
\text { (percent) }\end{array}$} & \multirow{2}{*}{$\begin{array}{l}\mathrm{pH} \\
1: 1 \\
\mathrm{H}_{2} \mathrm{O}\end{array}$} & \multirow{2}{*}{$\begin{array}{c}\text { Bulk } \\
\text { Density } \\
(g / c c)\end{array}$} \\
\hline & & Sand & silt & Clay & Frag. & & $1 / 3$ ATM. & 15 ATM & & & \\
\hline \multirow[t]{6}{*}{$\begin{array}{l}\text { Woodbridge } \\
\text { sandy loam }\end{array}$} & Ap & 48.6 & 43.6 & 7.8 & 2.3 & 1 & 28.4 & 14.9 & 4.62 & 4.40 & 1.02 \\
\hline & B21 & 33.5 & 44.1 & 2.4 & 6.3 & sl & 19.5 & 9.2 & .80 & 4.51 & 1.41 \\
\hline & $\mathrm{B} 22$ & 61.1 & 37.6 & 1.3 & 3.5 & sl & 13.8 & 4.7 & .37 & 4.54 & 1.54 \\
\hline & B3g & 63.1 & 35.7 & 1.2 & 3.8 & sl & 11.7 & 4.2 & .31 & 4.58 & 1.57 \\
\hline & $\mathrm{Clg}$ & 29.4 & 69.5 & 1.1 & 1.1 & sil & 16.6 & 4.8 & .13 & 4.71 & 1.64 \\
\hline & IICX & 73.5 & 25.3 & 1.2 & 15.0 & Is & 8.5 & 2.1 & - & 4.76 & 1.85 \\
\hline
\end{tabular}

\section{Plot 2}

sutton

$\begin{array}{lrrrrr}\text { Ap } & 51.5 & 38.7 & 9.8 & 3.1 & 1 \\ \text { B21 } & 56.1 & 41.8 & 2.1 & 9.4 & \mathrm{~s} 1 \\ \text { B22 } & 58.2 & 40.9 & .9 & 7.1 & \mathrm{~s} 1 \\ \text { B3 } & 60.0 & 34.8 & 5.2 & 6.1 & \mathrm{~s} 1 \\ \mathrm{Clg} & 25.1 & 73.0 & 1.9 & .8 & \mathrm{sil} \\ \mathrm{IICX} & 77.7 & 20.6 & 1.7 & 21.8 & \mathrm{ls}\end{array}$

32.5

21.7

13.7

13.1

19.6

7.4

$$
\begin{array}{r}
21.3 \\
12.6 \\
5.7 \\
4.5 \\
5.4 \\
1.9
\end{array}
$$

\subsection{6}

.90

.29

.27

.13

$-$

$\begin{array}{ll}4.35 & 1.09 \\ 4.55 & 1.42 \\ 4.58 & 1.44 \\ 4.65 & 1.48 \\ 4.71 & 1.50 \\ 4.93 & 1.78\end{array}$

1 1-loam; sl-sandy loam; sil-silt loam; ls-loamy sand. 


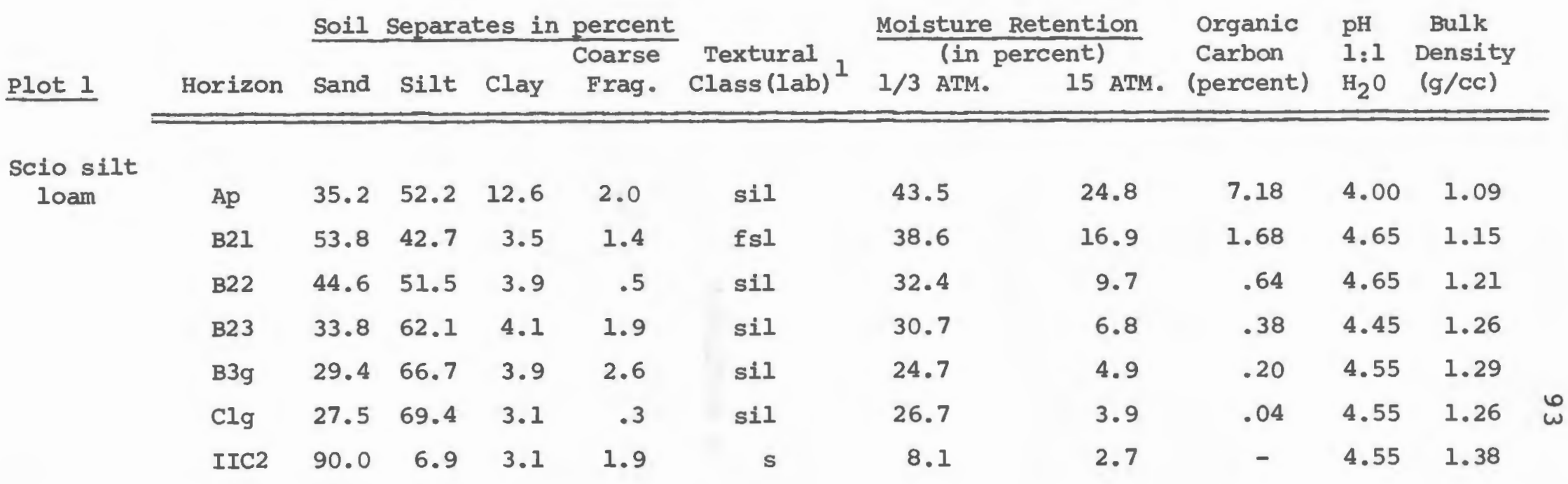

\section{Plot 2}

scio silt loam

$\begin{array}{lrrrrrr}\text { Ap } & 47.0 & 42.4 & 10.6 & 3.1 & 1 & 27.7 \\ \text { B21 } & 47.6 & 46.6 & 5.8 & 15.7 & \text { fsl } & 19.9 \\ \text { B22 } & 33.7 & 60.6 & 5.7 & 3.6 & \text { sil } & 20.6 \\ \text { B3g } & 29.1 & 68.6 & 2.3 & .8 & \text { sil } & 21.4 \\ \text { Clg } & 23.6 & 74.3 & 2.1 & .6 & \text { sil } & 22.3 \\ \text { C2 } & 43.0 & 52.7 & 4.3 & 18.9 & \text { sil } & 20.3\end{array}$

$\begin{array}{rrrr}13.1 & 2.43 & 4.35 & 1.02 \\ 9.6 & .58 & 4.58 & 1.38 \\ 8.3 & .37 & 4.58 & 1.33 \\ 6.5 & .24 & 4.59 & 1.34 \\ 6.2 & .11 & 4.66 & 1.41 \\ 6.5 & - & 4.62 & 1.36\end{array}$

1 sil-silt loam; fsl-fine sandy loam; s-sand; l-loam. 
APPENDIX C 


\section{NUTRIENT ANALYSIS FOR SCIO SILT LOAM ${ }^{1}$}

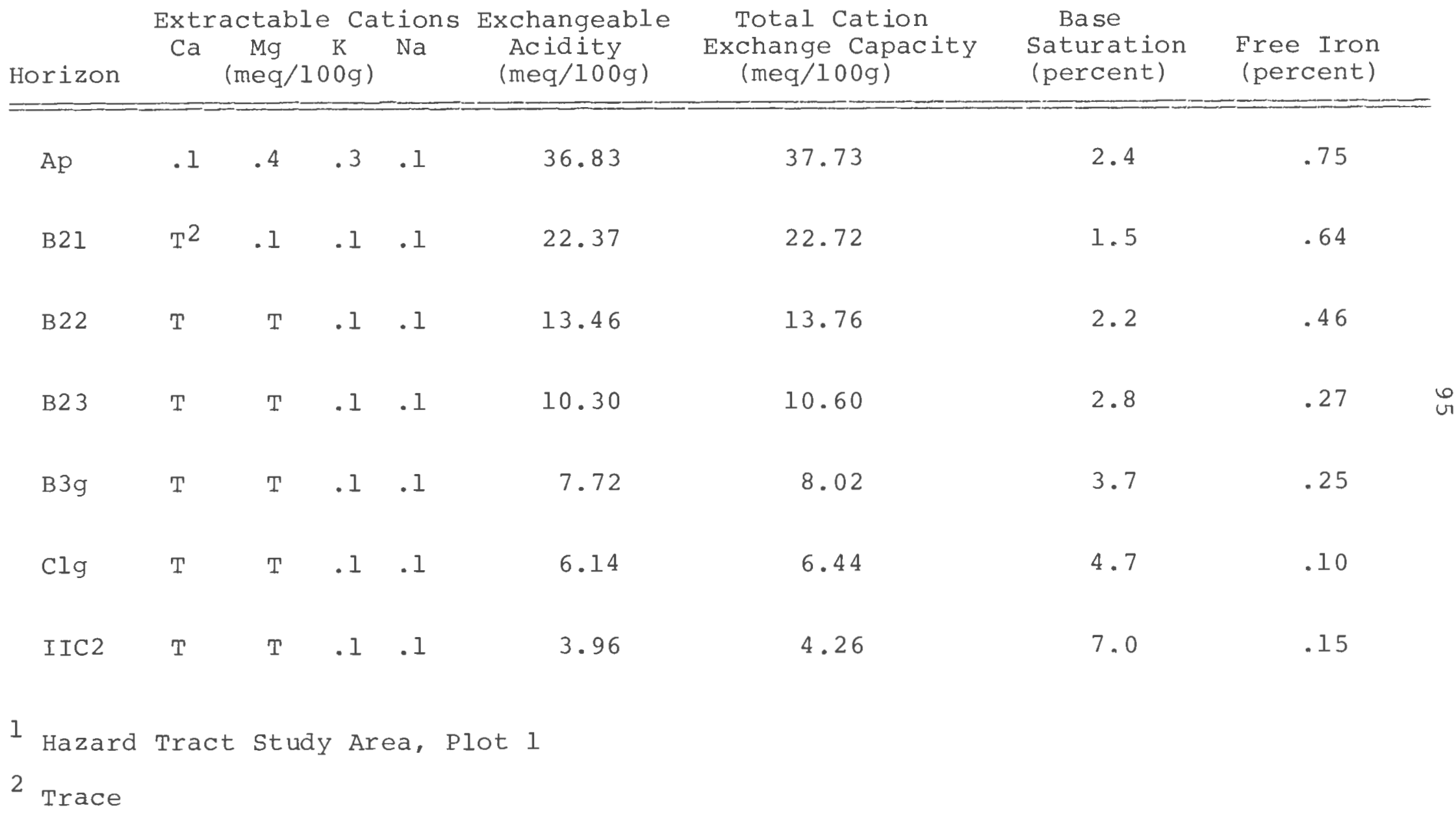


APPENDIX D 
SAMPLE TREE DATA FOR GREAT SWAMP I, PLOT 1

\begin{tabular}{|c|c|c|c|c|c|c|c|c|c|}
\hline $\begin{array}{l}\text { Sample } \\
\text { Tree }\end{array}$ & Species & $\begin{array}{c}\text { D.B.H. } \\
(\mathrm{cm})\end{array}$ & $\begin{array}{l}\text { Height } \\
\text { (m) }\end{array}$ & $\begin{array}{l}\text { Age } \\
\text { (yrs) }\end{array}$ & $\begin{array}{l}\text { Crown } \\
\text { Class }\end{array}$ & $\begin{array}{c}\text { Fresh } \\
\text { Weight }(\mathrm{kg})\end{array}$ & $\begin{array}{c}\text { Oven-dry } \\
\text { Weight }(\mathrm{kg})\end{array}$ & $\begin{array}{l}\text { Moisture } \\
\text { Content }(z)\end{array}$ & $\begin{array}{c}\text { Specific } \\
\text { Gravity }(g / c c)\end{array}$ \\
\hline 1 & WO & 8.64 & 7.62 & 41 & OT & 23.6 & 14.0 & 67 & -- \\
\hline 2 & wo & 8.64 & 5.79 & 25 & OT & 14.5 & 8.9 & 62 & -- \\
\hline 3 & wo & 9.14 & 9.14 & 38 & OT & 34.0 & 20.9 & 62 & - \\
\hline 4 & wo & 10.67 & 12.80 & 40 & OT & 52.6 & 31.9 & 65 & .56 \\
\hline 5 & wo & 12.70 & 10.36 & 45 & OT & 66.2 & 40.4 & 64 & -- \\
\hline 6 & wo & 13.21 & 12.50 & 47 & INT & 85.8 & 52.7 & 62 & .61 \\
\hline 7 & BO & 15.75 & 14.93 & 49 & $\mathrm{CD}$ & 150.4 & 89.5 & 69 & -- \\
\hline 8 & wo & 16.26 & 13.41 & 50 & $\mathrm{CD}$ & 165.4 & 100.7 & 63 & -- \\
\hline 9 & wo & 18.54 & 14.93 & 58 & $\mathrm{CD}$ & 255.2 & 156.5 & 62 & .58 \\
\hline 10 & $\mathrm{BO}$ & 19.05 & 14.63 & 55 & $\mathrm{CD}$ & 251.7 & 146.4 & 74 & -- \\
\hline 11 & $\mathrm{BO}$ & 19.81 & 16.15 & 57 & D & 298.1 & 175.3 & 72 & -- \\
\hline 12 & $\mathrm{BO}$ & 21.34 & 15.24 & 50 & $\mathrm{CD}$ & 380.7 & 221.2 & 75 & .63 \\
\hline 13 & $\mathrm{BO}$ & 22.35 & 15.24 & 55 & $C D$ & 399.2 & 231.9 & 74 & -- \\
\hline 14 & $\mathrm{BO}$ & 24.13 & 16.46 & 53 & D & 442.8 & 255.4 & 76 & .62 \\
\hline 15 & BO & 24.89 & 15.85 & 57 & D & 553.0 & 320.9 & 77 & -- \\
\hline 16 & BO & 25.40 & 16.76 & 57 & D & 596.3 & 359.2 & 68 & .65 \\
\hline
\end{tabular}

1 weighted average for entire tree on dry weight basis. 
SAMPLE TREE DATA FOR GREAT SWAMP I, PLOT 2

\begin{tabular}{|c|c|c|c|c|c|c|c|c|c|}
\hline $\begin{array}{l}\text { Sample } \\
\text { Tree }\end{array}$ & Species & $\begin{array}{l}\text { D.B.H. } \\
\text { (cm) }\end{array}$ & $\begin{array}{l}\text { Height } \\
\text { (m) }\end{array}$ & $\begin{array}{l}\text { Age } \\
\text { (yrs) }\end{array}$ & $\begin{array}{l}\text { Crown } \\
\text { Class }\end{array}$ & $\begin{array}{c}\text { Fresh } \\
\text { Weight }(\mathrm{kg})\end{array}$ & $\begin{array}{c}\text { Oven-dry } \\
\text { Weight }(\mathrm{kg})\end{array}$ & $\begin{array}{l}\text { Moisture } \\
\text { Content }(8) 1\end{array}$ & $\begin{array}{c}\text { Specific } \\
\text { Gravity (g/cc) }\end{array}$ \\
\hline 1 & RO & 7.62 & 7.62 & 48 & OT & 19.9 & 11.9 & 68 & -- \\
\hline 2 & $\mathrm{~T}$ & 8.13 & 7.01 & 28 & OT & 18.9 & 9.9 & 84 & .50 \\
\hline 3 & RO & 10.16 & 3.66 & 53 & OT & 21.0 & 11.8 & 79 & .61 \\
\hline 4 & wo & 11.94 & 4.57 & 47 & OT & 26.5 & 16.2 & 63 & .62 \\
\hline 5 & $\mathrm{RO}$ & 12.19 & 9.14 & 51 & OT & 79.4 & 43.2 & 87 & -- \\
\hline 6 & $\mathrm{BO}$ & 14.73 & 10.97 & 53 & INT & 139.3 & 83.0 & 70 & .65 \\
\hline 7 & BO & 16.51 & 12.80 & 54 & $\mathrm{CD}$ & 171.0 & 100.2 & 75 & -- \\
\hline 8 & BO & 18.03 & 14.02 & 54 & $\mathrm{CD}$ & 234.5 & 134.1 & 77 & -- \\
\hline 9 & BO & 19.05 & 15.24 & 54 & $\mathrm{CD}$ & 264.7 & 159.7 & 69 & -- \\
\hline 10 & BO & 20.32 & 14.02 & 52 & D & 298.4 & 176.3 & 70 & -- \\
\hline 11 & $\mathrm{BO}$ & 21.34 & 11.28 & 52 & $\mathrm{CD}$ & 262.3 & 154.7 & 70 & -- \\
\hline 12 & BO & 22.61 & 16.15 & 58 & $C D$ & 324.8 & 192.0 & 70 & -- \\
\hline 13 & BO & 22.86 & 15.24 & 56 & $C D$ & 432.1 & 252.0 & 73 & -- \\
\hline 14 & wo & 24.89 & 11.89 & 52 & D & 490.9 & 281.7 & 75 & .61 \\
\hline 15 & $\mathrm{BO}$ & 26.67 & 16.46 & 54 & $\mathrm{D}$ & 556.2 & 331.7 & 69 & -- \\
\hline
\end{tabular}

1 Weighted average for entire tree on dry weight basis. 
SAMPLE TREE DATA FOR GREAT SWAMP II, PLOT 1

\begin{tabular}{|c|c|c|c|c|c|c|c|c|c|}
\hline $\begin{array}{l}\text { Sample } \\
\text { Tree }\end{array}$ & Species & $\begin{array}{c}\mathrm{D} \cdot \mathrm{B} \cdot \mathrm{H} . \\
(\mathrm{cm})\end{array}$ & $\begin{array}{l}\text { Height } \\
\text { (m) }\end{array}$ & $\begin{array}{l}\text { Age } \\
(y r s)\end{array}$ & $\begin{array}{l}\text { Crown } \\
\text { Class }\end{array}$ & $\begin{array}{c}\text { Fresh } \\
\text { Weight }(\mathrm{kg})\end{array}$ & $\begin{array}{l}\text { Oven-dry } \\
\text { Weight (kg) }\end{array}$ & $\begin{array}{l}\text { Moisture } \\
\text { Content }(\%)\end{array}$ & $\begin{array}{l}\text { Specific } \\
\text { Gravity }(g / c c)\end{array}$ \\
\hline 1 & BO & 7.37 & 7.01 & 23 & OT & 21.2 & 11.8 & 76 & .68 \\
\hline 2 & BO & 8.38 & 8.23 & 23 & OT & 31.6 & 19.1 & 65 & .64 \\
\hline 3 & $\mathrm{RM}$ & 10.67 & 9.14 & 31 & INT & 55.9 & 33.7 & 65 & -- \\
\hline 4 & $\mathrm{RM}$ & 11.18 & 10.36 & 37 & INT & 48.9 & 31.0 & 55 & -- \\
\hline 5 & BO & 13.46 & 9.45 & 53 & INT & 101.3 & 55.8 & 84 & .61 \\
\hline 6 & $\mathrm{RM}$ & 13.97 & 10.97 & 56 & OT & 67.3 & 41.3 & 63 & -- \\
\hline 7 & BO & 15.24 & 10.06 & 52 & INT & 110.2 & 64.1 & 74 & .67 \\
\hline 8 & $\mathrm{RM}$ & 15.24 & 10.97 & 63 & INT & 116.5 & 71.0 & 63 & -- \\
\hline 9 & $\mathrm{RM}$ & 15.49 & 10.36 & 59 & $\mathrm{CD}$ & 97.4 & 61.8 & 57 & -- \\
\hline 10 & $\mathrm{RM}$ & 16.76 & 11.74 & 63 & $\mathrm{CD}$ & 140.8 & 87.2 & 61 & -- \\
\hline 11 & wo & 19.05 & 11.58 & 62 & $C D$ & 206.4 & 124.3 & 68 & -- \\
\hline 12 & wo & 20.32 & 12.50 & 61 & D & 300.4 & 181.2 & 65 & .66 \\
\hline 13 & wo & 20.57 & 13.41 & 57 & D & 313.3 & 188.2 & 67 & .61 \\
\hline 14 & $\mathrm{RM}$ & 22.86 & 15.24 & 70 & D & 315.4 & 195.6 & 60 & .63 \\
\hline 15 & $\mathrm{RM}$ & 25.91 & 15.85 & 73 & D & 375.1 & 235.8 & 58 & -- \\
\hline
\end{tabular}

1 Weighted average for entire tree on dry weight basis. 
SAMPLE TREE DATA FOR GREAT SWAMP II, PLOT 2

\begin{tabular}{|c|c|c|c|c|c|c|c|c|c|}
\hline $\begin{array}{l}\text { Sample } \\
\text { Tree }\end{array}$ & Species & $\begin{array}{l}\text { D. B.H. } \\
(\mathrm{cm})\end{array}$ & $\begin{array}{l}\text { Height } \\
\text { (m) }\end{array}$ & $\begin{array}{l}\text { Age } \\
\text { (yrs) }\end{array}$ & $\begin{array}{l}\text { Crown } \\
\text { Class }\end{array}$ & $\begin{array}{c}\text { Fresh } \\
\text { Weight }(\mathrm{kg})\end{array}$ & $\begin{array}{c}\text { Oven-dry } \\
\text { Weight (kg) }\end{array}$ & $\begin{array}{l}\text { Moisture } \\
\text { Content }(q)\end{array}$ & $\begin{array}{c}\text { Specific } \\
\text { Gravity }(g / c c)\end{array}$ \\
\hline 1 & Wo & 8.38 & 9.14 & 29 & OT & 22.9 & 14.7 & 70 & -- \\
\hline 2 & $\mathrm{RM}$ & 8.64 & 11.28 & 37 & INT & 38.5 & 23.8 & 61 & .57 \\
\hline 3 & $\mathrm{RM}$ & 10.92 & 12.19 & 33 & INT & 68.1 & 41.9 & 60 & -- \\
\hline 4 & $\mathrm{RM}$ & 11.43 & 13.11 & $5 \overline{3}$ & INT & 66.1 & 39.1 & 69 & .60 \\
\hline 5 & wo & 12.70 & 12.50 & 48 & $\mathrm{CD}$ & 78.5 & 45.5 & 71 & .64 \\
\hline 6 & $\mathrm{RM}$ & 12.95 & 12.19 & 57 & INT & 78.6 & 47.6 & 65 & -- \\
\hline 7 & $\mathrm{RM}$ & 15.24 & 10.06 & 48 & INT & 122.8 & 74.2 & 64 & -- \\
\hline 8 & wo & 15.75 & 11.89 & 60 & INT & 80.5 & 48.3 & 66 & .58 \\
\hline 9 & Wo & 18.29 & 14.63 & 56 & $C D$ & 274.1 & 168.4 & 61 & -- \\
\hline 10 & Wo & 19.05 & 13.11 & 58 & $C D$ & 241.5 & 148.0 & 66 & -- \\
\hline 11 & WO & 19.56 & 14.93 & 57 & D & 235.6 & 142.7 & 65 & -- \\
\hline 12 & $R M$ & 20.57 & 16.15 & 52 & $\mathrm{CD}$ & 280.2 & 177.8 & 57 & -- \\
\hline 13 & WO & 22.86 & 14.93 & 57 & $D$ & 348.3 & 202.7 & 72 & -- \\
\hline 14 & $S$ & 24.13 & 15.55 & 58 & $D$ & 376.7 & 209.4 & 82 & .48 \\
\hline 15 & $\mathrm{RM}$ & 25.15 & 18.90 & 61 & D & 454.7 & 279.2 & 61 & .57 \\
\hline 16 & WO & 25.91 & 15.85 & 61 & D & 530.8 & 323.5 & 64 & -- \\
\hline
\end{tabular}


SAMPLE TREE DATA FOR HAZARD TRACT, PLOT 1

\begin{tabular}{|c|c|c|c|c|c|c|c|c|c|}
\hline $\begin{array}{l}\text { Sample } \\
\text { Tree }\end{array}$ & Species & $\begin{array}{c}\text { D. B. H. } \\
(\mathrm{cm})\end{array}$ & $\begin{array}{l}\text { Height } \\
\text { (m) }\end{array}$ & $\begin{array}{l}\text { Age } \\
\text { (yrs) }\end{array}$ & $\begin{array}{l}\text { Crown } \\
\text { Class }\end{array}$ & $\begin{array}{c}\text { Fresh } \\
\text { Weight (kg) }\end{array}$ & $\begin{array}{c}\text { Oven-dry } \\
\text { Weight }(\mathrm{kg})\end{array}$ & $\begin{array}{l}\text { Moisture } \\
\text { Content }(z)\end{array}$ & $\begin{array}{c}\text { Specific } \\
\text { Gravity }(g / c c)\end{array}$ \\
\hline 1 & $\mathrm{RM}$ & 8.64 & 11.28 & 27 & INT & 32.1 & 21.4 & 46 & .54 \\
\hline 2 & Bo & 8.64 & 10.36 & 29 & INT & 33.9 & 21.5 & 57 & .64 \\
\hline 3 & BO & 10.41 & 12.19 & 32 & INT & 67.8 & 41.5 & 60 & -- \\
\hline 4 & $\mathrm{RM}$ & 10.92 & 13.11 & 37 & $C D$ & 67.6 & 43.5 & 53 & .56 \\
\hline 5 & BO & 11.68 & 12.19 & 36 & INT & 73.3 & 45.4 & 62 & -- \\
\hline 6 & RO & 12.70 & 14.02 & 37 & $\mathrm{CD}$ & 129.0 & 78.0 & 67 & .61 \\
\hline 7 & so & 16.00 & 15.55 & 35 & $C D$ & 212.8 & 118.3 & 82 & .62 \\
\hline 8 & $\mathrm{RM}$ & 16.26 & 14.63 & 34 & от & 139.1 & 88.8 & 57 & -- \\
\hline 9 & so & 18.03 & 15.55 & 41 & $\mathrm{D}$ & 211.9 & 119.3 & 80 & -- \\
\hline 10 & so & 18.29 & 16.15 & 36 & $\mathrm{CD}$ & 228.9 & 127.1 & 82 & -- \\
\hline 11 & so & 18.54 & 16.46 & 34 & D & 288.2 & 167.4 & 75 & -- \\
\hline 12 & so & 21.34 & 16.15 & 37 & D & 384.3 & 225.6 & 73 & -- \\
\hline 13 & RO & 21.59 & 15.85 & 36 & $\mathrm{CD}$ & 360.4 & 213.2 & 70 & - \\
\hline 14 & BO & 22.35 & 17.98 & 39 & $D$ & 399.6 & 221.1 & 87 & .63 \\
\hline 15 & BO & 22.86 & 17.37 & 43 & $\mathrm{D}$ & 430.9 & 245.7 & 79 & -- \\
\hline
\end{tabular}


SAMPLE TREE DATA FOR HAZARD TRACT, PLOT 2

\begin{tabular}{|c|c|c|c|c|c|c|c|c|c|}
\hline $\begin{array}{l}\text { Sample } \\
\text { Tree }\end{array}$ & Species & $\begin{array}{l}\text { D.B.H. } \\
(\mathrm{cm})\end{array}$ & $\begin{array}{l}\text { Height } \\
\text { (m) }\end{array}$ & $\begin{array}{l}\text { Age } \\
\text { (yrs) }\end{array}$ & $\begin{array}{l}\text { Crown } \\
\text { class }\end{array}$ & $\begin{array}{c}\text { Fresh } \\
\text { Weight (kg) }\end{array}$ & $\begin{array}{c}\text { Oven-dry } \\
\text { weight (kg) }\end{array}$ & $\begin{array}{l}\text { Moisture } \\
\text { Content }(8)^{1}\end{array}$ & $\begin{array}{c}\text { Specific } \\
\text { Gravity }(g / c c)\end{array}$ \\
\hline 1 & $\mathrm{RM}$ & 8.13 & 11.58 & 33 & $\mathrm{OT}$ & 29.8 & 18.0 & 64 & .50 \\
\hline 2 & SO & 8.89 & 10.67 & 35 & OT & 36.4 & 20.7 & 79 & -- \\
\hline 3 & wo & 8.66 & 10.67 & 37 & INT & 36.3 & 21.9 & 68 & .62 \\
\hline 4 & $\mathrm{RM}$ & 9.91 & 12.19 & 34 & INT & 46.4 & 29.1 & 59 & -- \\
\hline 5 & so & 10.41 & 11.89 & 32 & INT & 45.2 & 25.5 & 78 & .63 \\
\hline 6 & $\mathrm{RM}$ & 11.43 & 10.67 & 34 & INT & 59.6 & 35.3 & 67 & -- \\
\hline 7 & $\mathrm{BO}$ & 13.21 & 14.33 & 36 & INT & 119.6 & 68.2 & 76 & -- \\
\hline 8 & SO & 13.46 & 14.63 & 36 & INT & 99.1 & 56.8 & 75 & -- \\
\hline 9 & SO & 14.73 & 14.33 & 33 & INT & 150.5 & 87.9 & 73 & -- \\
\hline 10 & so & 14.99 & 14.93 & 33 & $\mathrm{CD}$ & 157.0 & 88.4 & 79 & -- \\
\hline 11 & so & 17.78 & 15.85 & 40 & $\mathrm{D}$ & 254.1 & 147.3 & 75 & .63 \\
\hline 12 & so & 18.54 & 15.55 & 32 & $C D$ & 280.9 & 164.8 & 73 & -- \\
\hline 13 & so & 20.32 & 16.46 & 34 & $\mathrm{D}$ & 345.1 & 190.8 & 85 & -- \\
\hline 14 & $\mathrm{RM}$ & 20.32 & 13.41 & 42 & $C D$ & 196.0 & 120.2 & 60 & .53 \\
\hline 15 & so & 25.40 & 15.55 & 37 & $\mathrm{D}$ & 617.8 & 360.0 & 74 & -- \\
\hline 16 & so & 27.43 & 16.76 & 39 & $\mathrm{D}$ & 612.8 & 351.2 & 78 & -- \\
\hline
\end{tabular}

1 Weighted average for entire tree on dry weight basis. 